\title{
Stylized Facts on Bilateral Trade and Currency Unions: Implications for Africa
}

\author{
Charalambos G. Tsangarides, Pierre Ewenczyk, \\ and Michal Hulej
}





\title{
IMF Working Paper
}

\author{
African Department
}

\section{Stylized Facts on Bilateral Trade and Currency Unions: Implications for Africa}

\author{
Prepared by Charalambos G. Tsangarides, Pierre Ewenczyk, and Michal Hulej ${ }^{1}$ \\ Authorized for distribution by Anne-Marie Gulde-Wolf
}

January 2006

\begin{abstract}

\section{This Working Paper should not be reported as representing the views of the IMF.} The views expressed in this Working Paper are those of the author(s) and do not necessarily represent those of the IMF or IMF policy. Working Papers describe research in progress by the author(s) and are published to elicit comments and to further debate.
\end{abstract}

This paper explores and quantifies several aspects of the performance of currency unions using an augmented version of the gravity model and focusing on two samples, the world and Africa. Our empirical findings suggest that, in principle, membership in a currency union should benefit Africa as much as it does the rest of the world. In addition, we find evidence from both samples that the effect of currency unions on trade is large, almost a doubling; currency unions are associated with trade creation, increase price co-movements among members, and make trade more stable; and longer duration of currency union membership brings about more benefits, although with some diminishing returns.

JEL Classification Numbers: F14, F15, F33

Keywords: Gravity model, trade, Currency Union

Author(s) E-Mail Address: ctsangarides@imf.org; pewenczyk@imf.org; mhulej@wne.uw.edu.pl

\footnotetext{
${ }^{1}$ We thank, without implicating, Xavier Debrun, Anne-Marie Gulde-Wolf, Cathy Pattillo, Andrew Rose, Sylvana Tenreyro, and Mahvash Qureshi for valuable comments and suggestions. All remaining errors are our responsibility. Michal Hulej is currently a doctoral candidate at Warsaw University and was an IMF summer intern at the time the research was conducted.
} 


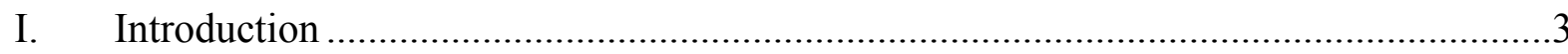

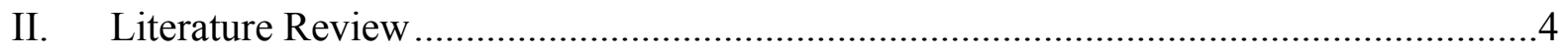

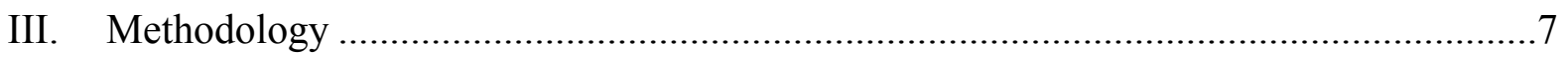

A. Analytical Framework .................................................................................... 7

B. Other Estimation Issues .......................................................................... 9

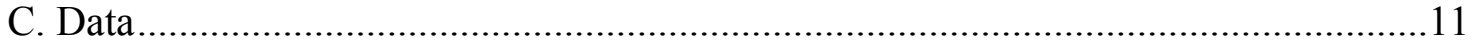

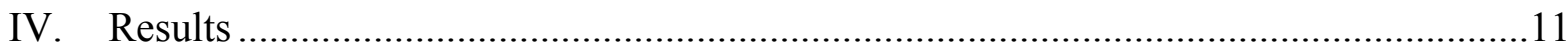

A. The Trade-Generating Effect in the World and Africa .........................................11

B. Years of Memebrship, Co-movements, and Trade Stability ..................................14

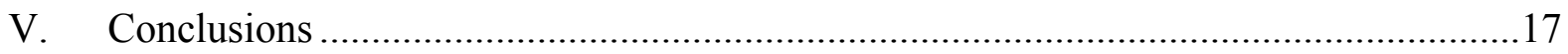

Figures

1. Dissolution of Currency Union: World Sample................................................... 18

2. Dissolution of Currency Union: Africa Sample................................................... 18

Tables

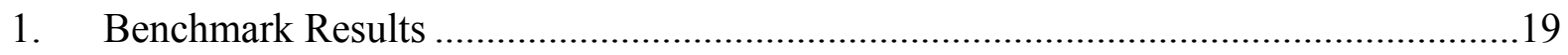

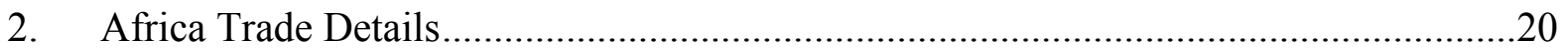

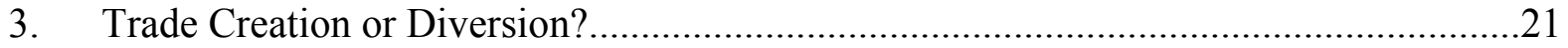

4. Sensitivity Analysis of Currency Union Effect ......................................................22

5. Duration of Currency Union Membership..................................................................23

6. Currency Union Impact on Co-movements of Outputs and Prices...............................24

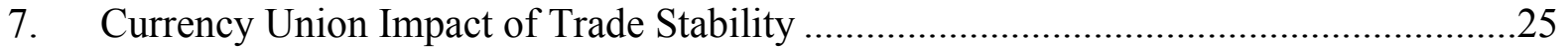

Appendices

A. Main African Regional and Subregional Economic Intgration Arrangements .............26

B. Sample Data: Variable Definitions and Sources ................................................27

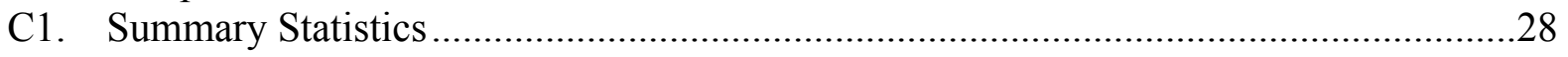

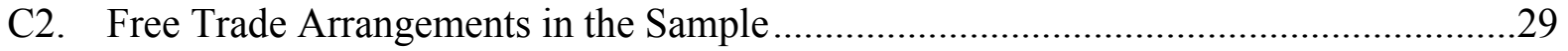

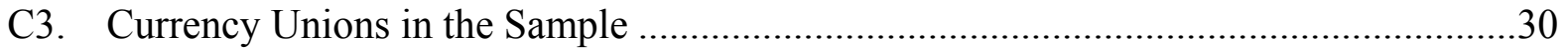

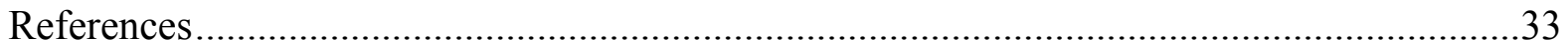




\section{INTRODUCTION}

Analogues of Newton's theory of gravity have been applied in a number of different contexts in attempts to explain interactions with spatial dimensions such as trade or migration. Although gravity models to estimate bilateral trade were originally introduced by Pöyhönen (1963) and Tinbergen (1962) as atheoretical (albeit plausible) empirical models, subsequent work established micro foundations for the basic building blocks that appear in these gravity models. ${ }^{2}$ Gravity models, shown to be fairly effective in modeling bilateral trading patterns, explain more than half of the variation in trade.

Recent work by Andrew Rose and a number of coauthors (for example, Rose, 2000; Frankel and Rose, 2002; Rose and van Wincoop, 2001; and Glick and Rose, 2002) has used gravity models to investigate, from an empirical point of view, the impact that currency arrangements have on bilateral trade. Frankel and Rose (2002) support the view that the important growth enhancing benefits of currency unions come only through increased trade and not through other channels (such as reduced inflation). Specifically, Frankel and Rose conclude that two countries that share the same currency trade roughly three times as much as they would if they used different currencies. ${ }^{3}$

From a theoretical standpoint, currency unions reduce transaction costs between trading partners and thus promote trade; they create a larger market in which there are potential gains from economies of scale and production efficiency (assuming factor mobility and flexible wages); they bring macroeconomic stability by signaling the central bank's commitment to reduce inflation; they enhance the credibility of the monetary authority; and they reduce uncertainty. Less uncertainty about prices can help allocate resources more efficiently in a region, while the absence of exchange rate risk in countries sharing a common currency encourages investment and facilitates capital mobility. These potential gains need to be compared with the potential losses from membership. Potential losses depend on the extent to which countries in the union face asymmetric shocks, and whether countries in the region are sufficiently flexible to absorb or mitigate such shocks, with factor mobility and transfers acting as shock absorbers.

This paper contributes to the ongoing debate about how currency unions affect trade by empirically investigating certain stylized facts of currency unions in Africa, and the world, in general. We choose to focus on Africa because it has had a rich experience with currency unions, although its integration in world trade has remained limited. ${ }^{4}$ We begin by augmenting the gravity model of Glick and Rose (2002) to investigate some stylized facts about the impact of currency unions on trade, including possible trade diversion effects.

\footnotetext{
${ }^{2}$ Deardorff (1998) argues that the basic regressors of gravity models - distance and income - are actually implied by a wide variety of theoretical models. Also, Feenstra, Markusen, and Rose (2001) argue that empirical gravity models can be used to discriminate between alternative trade theories.

${ }^{3}$ Rose (2000) conducts numerous robustness checks of his overall results and finds that the statistical significance of the estimated parameters is robust to the choice of estimation technique, sample period, and choice of subsamples of countries. Rose and van Wincoop (2001) reach similar conclusions.

${ }^{4}$ See Appendix A for a chart of African regional economic integration arrangements. See Masson and Pattillo (2004) for a detailed discussion of Africa's experience with currency unions.
} 
Then, we examine the effect of the duration of currency union membership on bilateral trade, and the impact of currency unions on price and output co-movements and trade stability.

Our empirical findings suggest that African countries stand to benefit as much from currency union membership as countries in the rest of the world, and, therefore, currency union benefits are not region specific. Our findings, which are fairly robust to a variety of estimation techniques, can be summarized as follows. First, in investigating the effect of a currency union membership on trade, the results of both samples reveal that countries belonging to the same currency union trade about two times more with each other than do other comparable countries that do not share a currency. Second, for both samples, there is evidence that currency unions are associated with trade creation, trade stability, and increased co-movement of prices, but not with the co-movement of output among members. Third, we show that, for bilateral trade, it matters not only whether countries share a common currency but, if they do, for how long: the longer a country participates in a currency union, the greater the benefit is; however, the relationship is not linear, with some diminishing returns to membership in a currency union. Finally, while the main results hold true for both samples and the marginal effects and the mechanisms of transmission may vary across the regions, we find that currency unions can be an effective tool for stimulating trade. However, given the low trade base and the protracted period necessary following the establishment of a currency union to increase trade significantly, it can be inferred from the results that currency union membership could not be a primary tool to achieve high levels of trade in Africa.

The rest of the paper is organized as follows. Section II provides a short survey of the relevant literature. Section III describes the methodology, presenting the analytical framework, estimation issues, and the data sources. Section IV presents the results of the various estimations, including the benchmark results of the impact of currency unions on trade, the characteristics of Africa trade, the effects of the length of membership in a currency union, and the impact of currency unions on output and price synchronization. Section $\mathrm{V}$ provides concluding remarks.

\section{LITERATURE REVIEW}

Baldwin's (2005) survey of the evidence on how the volume of trade is affected by currency unions rightly places Andrew Rose's research at the center of this literature. Rose and his coauthors show that membership in a currency union promotes trade substantially. Rose (2000) shows that trade between countries belonging to the same currency union is over three times greater than trade between comparable countries that do not share the same currency. He also shows that the effect of the decrease in exchange rate volatility is positive, although the coefficient is much smaller than the one associated with the currency union. In fact, the increase in trade associated with a currency union is over an order of magnitude larger than that associated with decreasing exchange rate volatility to zero. In answering the question of why sharing a currency has such a big effect on trade, Rose presents several reasons, including that a common currency can induce financial integration with its subsequent effects 
on trade and that, by entering a currency union, a government signals its commitment to long-term integration. ${ }^{5}$

Investigating further the trade generating effect of currency union membership, Rose and van Wincoop (2001) use a structural model developed by Anderson and van Wincoop (2003) to address country-specific idiosyncrasies. This approach, which was applied only to countries with complete bilateral data, reduces the effect of currency unions on trade to about two and a half. Exploring the time-series dimension of the data, Glick and Rose (2002) use a fixedeffects estimator to address the time-series element of the country-specific idiosyncrasies, namely, the pair-specific idiosyncrasies. They find a smaller, yet still large impact of currency unions on trade: joining a currency union almost doubles bilateral trade. In summary, while part of the recent debate (see Baldwin, 2005) has centered around the large magnitude of the estimated currency union effect, there seems to be an agreement in the literature that there is indeed a common-currency effect, which, as suggested by Frankel (2005), "is probably substantially smaller than a tripling."6

There is a growing literature describing the potential channels through which a currency union affects trade. Alesina and Barro (2002) show that, apart from country size and trade volume with a potential anchor, the characteristics that matter are co-movement of prices, comovement of outputs, inflation, and the volatility of inflation. They conclude that countries that may gain the most from joining currency unions are those with a history of high and volatile inflation and those having the largest co-movements of outputs and prices with a potential anchor. The predictions of Alesina and Barro (2002) are also tested by Tenreyro (2001). Using a probit model, the determinants of currency union are investigated, taking into account geography, colonial past, and price and output co-movements. Controlling for distance, cultural links, and colonial past, it is shown that countries with higher comovements of prices have a higher propensity to form a currency union, whereas comovement of outputs has no effect on countries' decision. ${ }^{7}$ Finally, Alesina, Barro, and Tenreyro (2002) and Tenreyro and Barro (2003) analyze the impact of currency union on comovements of outputs and prices between trading partners and investigate how comovements of outputs and prices would respond to the formation of a currency union. ${ }^{8}$

Africa presents an interesting area in which to assess the relative impact of currency unions and free trade agreements on intraregional trade as well as on trade with the rest of the

\footnotetext{
${ }^{5}$ However, he acknowledges that the effect may be smaller for modern industrial countries; most currency unions in Rose's (2000) sample comprise small or poor countries or both.

${ }^{6}$ Rose (2004) performs a "meta-analysis" of the currency union effect by combining estimates from 34 other studies. Treating all estimates as having been generated by the same process, Rose estimates a range of 30 to 90 percent for the currency union effect.

${ }^{7}$ Based on these results, Tenreyro constructs an instrumental variable for currency union that is used in a gravity model to account for the possible trade-currency union endogeneity. Persson (2001) uses a similar logit regression to find pairs of countries with a similar propensity to adopt a common currency but only one pair actually sharing the same currency. This matching procedure is then used in his nonparametric estimation of the gravity model.

${ }^{8}$ See Frankel and Rose (1998) and Frankel and Rose (1997) for a discussion of the endogeneity of optimum currency areas criteria.
} 
world. ${ }^{9}$ Currency unions and preferential regional trade agreements have been an important component of trade policy in African countries over the past few decades. However, despite these initiatives, the participation of African countries in world trade remains limited. Various explanations have been given for Africa's trade marginalization, including slow economic growth, unfavorable geographical and exogenous factors, poor infrastructure and transport policies, poor trade policies, and the poor effectiveness of currency unions restrained by barriers to intraregional trade, and constraints to factor mobility. In addition, the substantial savings on transaction costs and the trade benefits that would accrue from a monetary union may be limited in Africa because of lesser diversification and the asymmetric terms of trade shocks hitting the economies. ${ }^{10}$ Furthermore, the loss of the nominal exchange rate instrument makes real adjustments to asymmetric shocks more difficult, especially in view of the poor systems of fiscal transfers and the limited development of the banking and financial sectors in Africa.

Looking at the empirical work on Africa, Debrun, Masson, and Pattillo (2005) show that gains from adopting a common currency depend, among other factors, on the correlation of terms of trade shocks. This, in turn, is connected to countries' dependence on primary commodity prices. In addition, they show how the existence of interest groups affects incentives to join a currency union or accept a new member in a multilateral union. This effect, especially important for Africa, is crucial for gains and losses from participating in a currency union because differences in government spending propensities may be more important than asymmetric shocks. Coe and Hoffmaister (1999) analyze North-South trade and show that, on average, Africa trades more than developing countries in other regions. Subramanian and Tamirisa (2003) highlight the importance of distinguishing between Anglophone and Francophone Africa in assessing the integration of countries in the region with global markets. Finally, Masson and Pattillo (2004) examine the impact of currency unions on trade in Africa using the Glick and Rose (2002) specification. They estimate that the effect of the currency union dummy on African bilateral trade (which includes African countries' trade with the rest of the world) is almost the same as in their world sample, with currency unions increasing trade by a factor of three for both Africa and the world. ${ }^{11}$

Our paper contributes to the existing empirical work in the literature in several ways. First, we separate the empirical analysis in two samples, the world and Africa, to investigate whether Africa's experience is different. Second, we add several modifications to the standard gravity model estimations, including variables for free trade area, trade diversion, and membership duration, as well as extend the sample of coverage and period compared with earlier empirical work. Third, we investigate and quantify a series of "stylized facts" relating to the trade and currency union nexus, including the trade-generating impact of

\footnotetext{
${ }^{9}$ Carrere (2004) provides an assessment of the trade impact of African regional agreements.

${ }^{10}$ See, among others, Collier (1995), Rodrik (1998), Yeats (1998), Collier and Gunning (1999), Limao and Venables (2001), and Subramanian and Tamirisa (2003).

${ }^{11}$ Masson and Pattillo (2004) analyze the impact of currency unions on trade in Africa using the Free Trade Area (FTA) definition from Glick and Rose (2002), which does not distinguish between FTA and currency union effects. As discussed in the results section, our data set permits this distinction and we explore this estimation.
} 
currency union membership, the effect of currency unions on trade stability, and price and output co-movements.

\section{Methodology}

\section{A. Analytical Framework}

Gravity models represent trade between two economies as a function of their respective economic masses, the distance between the two economies, and a variety of other factors. In line with earlier literature, we begin by investigating the effect of currency unions on trade by defining the following augmented gravity model:

$$
\log \left(X_{i j}\right)=\beta_{0}+\sum_{k=1}^{N} \beta_{k} Z_{k}+\gamma C U_{i j},
$$

where $i$ and $j$ denote the exporting and importing countries, respectively; $t$ denotes time; $X_{i j t}$ denotes the value of bilateral trade between $i$ and $j ; C U_{i j}$ is a binary variable that is unity if $i$ and $j$ share the same currency; ${ }^{12} \gamma$ is the estimate of the currency union tradegenerating effect; and $Z_{k}$ is a vector consisting of gravity variables. The $Z_{k}$ vector includes $\ln \left(Y_{i} Y_{j}\right), \ln \left(\frac{Y_{i} Y_{j}}{\text { Pop }_{i} \text { Pop }_{j}}\right), \ln D_{i j}$, Cont $_{i j}, \operatorname{Lang}_{i j}, F_{T A} A_{i j}$, ComNat $_{i j}, \operatorname{ComCol}_{i j}, \operatorname{Col}_{i j}$, and $\ln \left(\right.$ Area $_{i}$ Area $\left._{j}\right)$, where $Y$ is real GDP; Pop is population; $D_{i j}$ is the distance between $i$ and $j$; Cont $_{i j}$ is a binary variable, which is unity if $i$ and $j$ share a land border; Lang $_{i j}$ is a binary variable, which is unity if $i$ and $j$ have a common official language; $F T A_{i j}$ is a binary variable, which is unity if $i$ and $j$ belong to the same regional trade agreement; ComNat $_{i j}$ is a binary variable, which is unity if $i$ and $j$ are the part of the same nation; $\mathrm{ComCol}_{i j}$ is a binary variable, which is unity if $i$ and $j$ were colonies after 1945 of the same colonizer; $C_{i j} l_{i j}$ is a binary variable, which is unity if $i$ colonized $j$ or vice versa; and Area $_{n}$ is the land area of country $n$ with $n=i, j$.

Next, we investigate the possibility that the stimulus to trade among members of a currency union comes at the expense of trade with nonmembers' diversion. Following Frankel and Rose (2002), we define a dummy variable that is unity if the two countries are not in the same currency union but (at least) one is in a currency union with another country. A negative (and significant) coefficient of this variable would indicate the existence of potentially harmful trade diversion, and could be interpreted as implying that the increased trade among members inside the union comes at the expense of trade with nonmembers.

\footnotetext{
${ }^{12}$ The definition of "currency union" (which follows from Glick and Rose, 2002) implies that money was interchangeable between the two countries at a 1:1 par for an extended period of time, so that there was no need to convert prices when trading between a pair of countries. Under this definition, hard fixes are not identified as currency unions. Further, the definition of currency union is transitive: if country pairs $X, Y$ and $X, Z$ are in a currency union, then $Y$ and $Z$ are in a currency union.
} 
Then, we investigate the effects of membership duration. We construct another variable of interest - the number of years that a given pair of countries shares a common currency - and we modify equation (1) to include a variable to capture duration in a currency union as follows: ${ }^{13}$

$$
\log \left(X_{i j}\right)=\beta_{0}+\sum_{k=1}^{N} \beta_{k} Z_{k}+v(\text { years } C U)_{i j}
$$

In order to investigate the impact of currency unions on co-movements of output and prices, we construct the variables measuring co-movement of prices and output that are used as dependent variables in equation (1), following Alesina, Barro, and Tenreyro (2002). Specifically, the price co-movements are computed as follows: for every pair of countries, we use annual price data to compute residuals from second-order autoregression equation estimated for each pair of countries for which we have more than 20 observations:

$$
\ln \left(\frac{P_{i t}}{P_{j t}}\right)=b_{0}+b_{1} \ln \left(\frac{P_{i, t-1}}{P_{j, t-1}}\right)+b_{2} \ln \left(\frac{P_{i, t-2}}{P_{j, t-2}}\right)+\varepsilon_{t i j} .
$$

Estimated residuals from equation (3) are then used to obtain a measure of co-movement of prices, with higher $V P_{i j}$ representing greater synchronization of prices between countries $i$ and $j$ :

$$
V P_{i j}=-\sqrt{\frac{1}{T-3} \sum_{t=1}^{T} \hat{\varepsilon}_{t i j}^{2}} .
$$

In a similar fashion, we construct a measure of co-movement of output, with $\hat{u}$ denoting estimated residuals from the following autoregressive process:

$$
\ln \left(\frac{Y_{i t}}{Y_{j t}}\right)=b_{0}+b_{1} \ln \left(\frac{Y_{i, t-1}}{Y_{j, t-1}}\right)+b_{2} \ln \left(\frac{Y_{i, t-2}}{Y_{j, t-2}}\right)+u_{t i j},
$$

and

$$
V Y_{i j}=-\sqrt{\frac{1}{T-3} \sum_{t=1}^{T} \hat{u}_{t i j}^{2}} .
$$

Finally, to assess the currency union impact on trade stability, we follow Rose (2005) and estimate an equation similar to the gravity equation with the coefficient of variation of $\log$ of real trade as dependent variable of equation (1). We calculate values for the dependent variable for the periods 1950-1976 and 1976-2003, so we have two observations per pair. In addition, as a robustness check of the dependent variable, we use (i) the maximal absolute value (during the 27-year sample period) of the difference between the log of real trade and the sample average of trade of every country, scaled by the sample average; (ii) the mean absolute value of the difference between exports and their sample average of every country (scaled by average exports); and (iii) the standard deviation of the residual from a

\footnotetext{
${ }^{13}$ Because our data begin in 1948, we ignore years spent in a currency union before that date. To be strict, we may define our variable as years spent in a currency union after 1948.
} 
conventional gravity equation of exports in levels. All the explanatory variables are averaged over the corresponding time periods.

\section{B. Other Estimation Issues}

In this section we discuss several methodological issues before proceeding with the estimations. These issues are derived primarily from various critiques of the gravity equation analyses, including the three "classic gravity model mistakes" Baldwin (2005) labels as gold, silver and bronze medal mistakes. ${ }^{14}$ To the extent that these critiques relate to our analysis, we discuss our attempts to address them through robustness checks of our results.

First, we begin with the issue of omitted variables and biases stemming from omitted variables that are pro-trade and correlated with the currency union dummy, labeled as the "gold medal mistake" in Baldwin's (2005) critique. Research following the initial Rose (2000) results attempts to control for the omitted variable bias by introducing countryspecific idiosyncrasies in the model, both in the context of cross-section and panel estimations. First, in the context of cross section analysis, country fixed-effects are used to account for the Anderson and van Wincoop "multilateral resistance" factor, according to which trade between two countries does not depend only on the characteristics of those countries but also on the barriers between those countries and the rest of the world. ${ }^{15}$ However, given that there is a time-series element to the potential bias that is not eliminated with the Anderson and van Wincoop (2003) procedure, a panel data fixed-effects procedure (robust fixed-effects "within" estimator) is employed that adds country-pair specific intercepts to the equation, and thus exploits the time-series dimension of the data around country-pair averages. To address the omitted variable bias issue, we first follow the literature in estimating the gravity equation using ordinary least squares; then we estimate the specifications with fixed-effects as in Glick and Rose (2002); and, finally, we use panel data techniques (the random effects and robust fixed-effects "within" estimator). ${ }^{16}$

Second, since forming a currency union (or continuing to stay in a currency union) may also be an endogenous choice, some of the large trade-creating effects of currency union may actually be a reflection of reverse causality. The use of instrumental variables could be a solution to the potential endogeneity problem. However, an appropriate instrument for a currency union is hard to find, which is further complicated by the fact that the currency union variable is a dummy variable. Nevertheless, attempts by Alesina, Barro, and Tenreyro (2002) to address the endogeneity problem using an instrumental variable based on client anchor relationship, have shown that the effect of currency union on trade still remains high even after accounting for this potential endogeneity. In addition, Rose and van Wincoop

\footnotetext{
${ }^{14}$ For more details, see Baldwin (2005) and Frankel's comments on the Baldwin paper (Frankel, 2005).

${ }^{15}$ In Anderson and van Wincoop (2003) the national price indices ( $P_{i}$ and $P_{j}$ ) account for the "multilateral resistance" between countries $i$ and $j$. They propose an iterative method to estimate $P_{i}$ and $P_{j}$, but since the process is complex they propose an alternative method that is preferred in the empirical work: namely, estimating implicit prices by fixed-effects, i.e. country-specific dummy variables.

${ }^{16}$ In all regressions we include year effects and allow for clustering of the error terms within country pairs.
} 
(2001) argue that: "reverse causality also does not explain away the findings; there is little evidence in the political science literature that countries join currency unions to increase trade, and instrumental variables only increase the impact of currency unions on trade." This political dimension is particularly important for the case of Africa. Masson and Pattillo (2004) underscore the political dimension of the decision to form or participate in a currency union and suggest that the experience of Africa shows that political objectives are important to the formation of monetary unions. ${ }^{17}$ Based on the arguments above, and because the Alesina, Barro, and Tenreyro (2002) instrument is not designed for multilateral currency unions (which is of special interest to the Africa focus of our paper), in our analysis we choose to treat currency unions as an exogenous variable with respect to trade.

Finally, there are several issues relating to the model misspecification. Some of the criticisms in the literature relate to the aggregation of exports and imports in the estimation, inappropriate deflation of nominal trade values by the U.S. aggregate price index, possible nonlinear effects entering the gravity equation, and the use of zero-trade observations in the sample. ${ }^{18}$ On the aggregation issue, some critics argue that while theory supports the use of bilateral exports as dependent variable, the use of bilateral trade as the dependent variable without properly aggregating imports and exports can seriously bias the results. In order to address this critique, we check the sensitivity of our results when the dependent variable used is the sum of the logarithm of exports and imports as well as the logarithm of the sums (the "silver medal of classic gravity model mistakes" as defined by Baldwin). Next, to account for the potential bias possibly arising from inappropriate deflation by the aggregate U.S. price index, we add time dummies. This procedure corrects for the global trends in inflation rates, as every bilateral trade flow is divided by the same price index adjusted for time effects (Baldwin's "bronze medal of classic gravity model mistakes"). Furthermore, in order to address the possibility of non-linear effects operating in the gravity equation estimations (as for example, due to sample non-homogeneity), similarly to Glick and Rose (2002), we add quadratic terms for both output and output per capita. Finally, the treatment of zero-trade observations is an issue, as the log-linear form of the gravity equation (1) requires using observations for which the dependent variable is positive. ${ }^{19}$ Given that the value of trade flows between some pairs of countries-typically pairs of small countries-may be zero, a sample selection problem may arise, the severity of which depends on the particular characteristics of the sample and model used. In order to address this issue, we use a positive constant that allows the inclusion of the zero-trade observations, namely, using $\log \left(\right.$ cons $\left.\tan \mathrm{t}+X_{i j}\right)$ as a dependent variable in order to avoid the truncation; and Tobit

\footnotetext{
${ }^{17}$ The CFA franc zone and the CMA were formed due, in large part, to the political self-interest of the major power (France in the former case, and South Africa in the latter).

${ }^{18}$ The first two in this list are what Baldwin (2005) calls the "silver and bronze medal mistakes." The issue of nonlinearities is also discussed in Baldwin. See also Frankel (2005) for a justification of using the "pooled" export-import specification.

${ }^{19}$ While, in many cases, zeros occur simply because some pairs of countries did not trade in a given period, zeros may be the result of rounding errors or missing observations that are wrongly recorded as zero. These problems are more likely to occur when small countries are considered. Dropping pairs of countries with zerotrade flows and estimating the log-linear form using ordinary least squares may create a truncation problem and result in inconsistent estimators. See Santos Silva and Tenreyro (2004) for a discussion of these issues.
} 
estimation to appropriately account for the censored nature of the dependent variable of the model. $^{20}$

\section{Data}

We extend Glick and Rose's data set (2002) to include 217 countries and other political units over the time period 1948-2002. ${ }^{21}$ The full set of countries represents the world sample in our analysis. The Africa sample consists of 49 countries from the world sample where at least one in the $i j$ pair is an African country. We also investigate intra-Africa and Africa trade with the rest of the world (Africa-ROW). The intra-Africa sample includes countries where both $i$ and $j$ in the pair come from Africa. The Africa-ROW sample includes exactly one country from Africa in each $i j$ pair. ${ }^{22}$

The data sources for the first part of the paper include annual bilateral trade observations from the IMF's Direction of Trade Statistics (expressed in real U.S. dollars); GDP data from the University of Pennsylvania World Tables 6.1 and the World Bank's World Development Report; colonial past, distance, and language are variables from the CIA World Factbook 2004; data on currency unions for the period 1998-2002 are from the IMF's Exchange Arrangements and Exchange Restrictions Annual Report; and data on free trade agreements and currency unions are from Glick and Rose. ${ }^{23}$ For the second part of the paper, we use data on prices (purchasing power parity of GDP) from Penn World Tables 6.1; and terms of trade data are from the IMF's World Economic Outlook 2004. Appendix B provides more details on the data construction and sources. Appendix $\mathrm{C}$ presents the countries, currency unions, and free trade agreements used in the study as well as summary statistics for the variables of interest.

\section{IV.RESULTS}

\section{A. The Trade-Generating Effect in the World and Africa}

We begin by investigating general aspects of bilateral trade with the extended sample and draw comparisons between the world and Africa samples. First, using the gravity equation (1) we establish some benchmark results by extending the results of Glick and Rose (2002) to allow the free trade agreement dummy to include agreements operating in Africa (which Glick and Rose neglect since these were not included in the World Trade Organization database they were using). Then, we estimate the characteristics of bilateral trade in Africa, trade creation, and address robustness issues.

\footnotetext{
${ }^{20}$ The pseudo maximum likelihood approach developed by Santos Silva and Tenreyro (2004) also deals with potential heteroskedasticity and could be used as a robustness check.

${ }^{21}$ These include overseas territories, parts of kingdoms, possessions, self-governing territories in free association with another country, unincorporated territories, and crown dependencies.

${ }^{22}$ Hence, the number of observations the intra-Africa and Africa-rest-of-the-world samples sums to the total Africa sample.

${ }^{23}$ We added some free trade areas (FTAs) omitted in the Glick and Rose (2002) study, as well as FTAs operating in Africa (although not included in the World Trade Organization database).
} 


\section{Benchmark results}

Table 1 shows the benchmark results of estimating equation (1) using our extended sample. Following the literature, we use simple cross-section estimation (columns 1-3) and then extend the results using panel fixed-effects estimation in order to account for the country-pair specific idiosyncratic effects and address the potential omitted-variable bias (columns 4-6). The specification in the first column uses the world sample and replicates the benchmark cross-section results of Glick and Rose (2002) very closely: countries sharing a common currency trade more than two and a half times more than countries not involved in a currency union. The coefficients on the standard determinants of the gravity models, such as income, population, and distance, have the correct sign, are statistically significant, and yield plausible elasticity estimates broadly in line with those obtained in the literature. ${ }^{24}$ In column 2 , we allow the free trade area dummy to include more agreements, especially those operating in Africa (which is an important point because a major part of currency union operates in this region). The coefficient of currency union decreases slightly to 2.3 compared with the original Glick and Rose specification. The third column presents the estimation of equation (1) for the Africa sample. Interestingly, the currency union trade-generating effect is larger than in the world sample, and the marginal impacts of the other determinants change. ${ }^{25}$ In terms of the marginal impacts of the other determinants in the Africa sample compared with the world sample, the "common land border" variable becomes much more important, reflecting the poor transportation links between many African countries and the tendency to trade more with neighboring countries; "common language" is less important, since the currency unions in the sample are the Francophone countries of West and Central Africa and the South Africa Common Monetary Area; "ever colony" has a greater impact reflecting the colonial ties in Africa; and there is a reversal of the signs of "number of islands." Finally, we reestimate the specifications of columns 1-3 as a panel and add a set of country-pair-specific intercepts to the equation. ${ }^{26}$ As expected, the results in columns 4-6 show that accounting for country fixed-effects does change the results significantly, suggesting that the idiosyncratic effect is important. For both the world and Africa samples (columns 5 and 6), the size of the currency union coefficient falls, with the currency union trade-generating effect now slightly smaller in Africa. With country effects taken into consideration, currency union membership is estimated to boost trade by a factor of 1.8 and 1.7 in the world and Africa, respectively.

Next, we investigate the characteristics of African trade in more detail. Table 2 presents the results of the relative trade performance of African countries by introducing dummies for intra-Africa trade, and trade between Africa and the rest of the world (ROW). ${ }^{27} \mathrm{We}$ introduce these trade dummies in the baseline specification (shown in column 2 of Table 1). Doing so changes the currency union coefficient only marginally, suggesting that the trade-generating

\footnotetext{
${ }^{24}$ Henceforth, and unless discussed otherwise, this statement will hold true for all specifications discussed.

${ }^{25}$ Although Masson and Pattillo (2004) have also estimated this, our results may not be directly comparable to theirs because free trade areas operating in Africa were not included in the Masson and Pattillo estimation.

${ }^{26}$ While we estimate both fixed and random effects, we rely on the robust fixed-effects "within" estimator.

${ }^{27}$ As discussed earlier, the dummy for intra-Africa trade is unity if both countries are in this region; the AfricaROW trade is unity if only one country is located in Africa.
} 
effect of a currency union is now 2.2 times greater than for countries not in a currency union. In addition, both the Africa-ROW and intra-Africa trade dummies are highly significant. In columns 5 and 6 the sample is restricted to examine the Africa-ROW and intra-Africa trade with country-specific effects taken into consideration. The results confirm that currency union participation in Africa has beneficial intraregional trade generating effects as well as Africa-ROW trade-generating effects: the trade-generating effect is 1.8 for intra-Africa and 1.7 for Africa-ROW trade. Finally, following Subramanian and Tamirisa (2003), we also examine the distinction between Anglophone and Francophone countries. We find that the trade-generating effect is still high but, contrary to Subramanian and Tamirisa, we do not find any distinction in the trade patterns of Francophone and Anglophone Africa, since we find no evidence of intra-Francophone and intra-Anglophone undertrading. However, we do find evidence of increasing integration of both Francophone and Anglophone Africa with the rest of the world because the coefficients of global overall trade with the ROW are positive and significant, suggesting that, in Francophone and Anglophone Africa, overall trade was about 22 and 25 percent more than the average, respectively. ${ }^{28}$

In Table 3, we investigate the possibility that the stimulus to trade among members of a currency union comes at the expense of trade with nonmembers by adding the trade diversion dummy to the specifications of Tables 1 and 2. All the specifications where country-pair specific fixed-effects are properly accounted for show that the coefficients associated with the trade diversion dummy are positive for both the world and Africa samples. This suggests that there is a significant trade creation effect (rather than trade diversion), with Africa's trade creation effect slightly smaller in magnitude than the world sample. In addition, while there is a significant trade creation effect for both the intra-Africa and Africa-ROW specifications, the intra-Africa trade creation effect is about five times higher, which reflects observed trade patterns in Africa's trade arrangements. Finally, the overall currency union trade-generating effect still remains about 2.1 and 2.0 for the world and Africa, respectively.

\section{Sensitivity analysis}

We check the robustness of our results presented in Tables 1 and 2, by changing our methodology in a number of ways (see discussion in Section III.B.) and reporting estimates of the coefficients of interest. In particular, we conduct sensitivity checks of the specification by estimating the dependent variable as the average of the logarithm of exports and imports (rather than the logarithm of the average); adding quadratic terms for output and output per capita to control for possible sample nonlinearities; adding time effects; modifying the dependent variable by adding a small constant to trade before taking logarithm to avoid the truncation issue, essentially estimating $\log \left(\operatorname{constant}+X_{i j}\right)$ as the dependent variable; ${ }^{29}$ and using Tobit estimation to account for the censored nature of the dependent variable.

\footnotetext{
${ }_{28}^{28}$ For brevity, results are not included, but are available from the authors.

${ }^{29}$ Indeed, not eliminating the zero observations increases the world and Africa samples by about 45 and 31 percent, respectively. Also, in order to compare our results with those obtained by Alesina, Barro, and Tenreyro (2002) we set this constant equal to 100 . Therefore, the dependent variable becomes $\log \left(100+X_{i j}\right)$.
} 
The results in Table 4 show that the estimates of the currency union trade-generating effect $\gamma$ are reasonably insensitive to a number of sensitivity checks of our methodology. First, adding nonlinear terms, time effects, and changing the specification of the dependent variable to one of the average of the logs changes only marginally the magnitudes of the benchmark fixed-effects estimates. Second, adding the zero-trade values can make a difference in the results. It is important to acknowledge, however, that while excluding the zero values eliminates observations for which the currency union elasticity is low in absolute value may drive the overall elasticity upwards (Anderson and van Wincoop, 2003), at the same time, inclusion of the zero values may drive the overall elasticity downward. ${ }^{30}$ The Tobit estimates, which overcome the bias that may result from the censored nature of the data, are sufficiently close to the cross-section benchmark results obtained in Table 1, but may, however, suffer from the omitted-variable bias resulting from not properly accounting for country-pair specific fixed-effects. In summary, the estimated $\gamma$ from the fixed-effects estimates lies in the narrow range of about $(1.17,1.89)$ and $(1.03,1.85)$ for the world and Africa samples, respectively. When we include only statistically significant estimates and exclude the estimates resulting from corrections relating to zero-trade observations, the range becomes even more tight $(1.59,1.89)$ and $(1.68,1.85)$ for the world and Africa samples, respectively.

\section{B. Years of Membership, Co-movements, and Trade Stability}

We now turn our attention to three related (but different) issues. We investigate the impact of the duration of currency union membership on bilateral trade, the currency union impact on output and price co-movements, and the effect of currency union membership on trade stability. Finally, similarly to the previous section, we discuss robustness issues.

\section{Benchmark results}

Investigating the time-dimension aspect of a currency union, we follow Glick and Rose (2002) to estimate how the effects of leaving a currency union evolve over time. To do so, we define a dummy variable that is equal to unity for the observations associated with the year of a union's dissolution between a given pair of countries, and equal to zero otherwise. ${ }^{31}$ More important, we also include lags of this dummy (we add a dummy variable for one year after dissolution, for two years after dissolution, and so on). Figures 1 and 2 plot the coefficients of subsequent lags to trace out the response of bilateral trade to the dissolution of a currency union. ${ }^{32}$ Because our sample extends the time-dimension of the Glick and Rose data set, we show more convincingly that the exits from a currency union are associated with a decline in bilateral trade. For both samples of our analysis, the effect is not quite visible (and statistically significant) until about 21 years after the country exits the currency union,

\footnotetext{
${ }^{30}$ See Amemiya (1984) for a detailed discussion on this and the benefits of using Tobit estimation.

${ }^{31}$ See Appendix $C$ for the number of identified currency union dissolutions for the world and Africa samples.

${ }^{32}$ The horizontal lines in Figures 1 and 2 correspond to the estimate of the coefficient of the currency union dummy (namely, the $\gamma$ coefficient for the gravity equation (1) extended to include the vector of lagged variables described in the text) for the world and Africa samples, respectively. The 95 percent confidence intervals are also included.
} 
and some negative effects in absolute terms can be identified only after 30 years. ${ }^{33}$ For both the Africa and world samples, no statistically significant negative effects are identified in the years immediately after the dissolution of the currency union; statistically significant coefficients for the world and Africa samples, respectively, appear in the periods of 16-27 years and 16-21 years after leaving the currency union. In addition, the adverse effect of exiting from a currency union is smaller for the African sample in the first few years: after ten years of currency union exit, bilateral trade declines by about 35 percent for the Africa and 55 percent for the world. However, 10 years after the exit, the cumulative decline in bilateral trade is greater in Africa than in the world sample. Overall, the results suggest that the impact of leaving a currency union is far from linear, which motivates the inclusion of a quadratic term in the currency union duration effect analysis.

Next, since it is not possible to determine the effects of joining a currency union in a similar fashion (because there are too few currency union entries in the sample), we take the following approach: instead of measuring the trade effects that occur after a country enters a currency union, we ask how the trade effects of a currency union evolve over membership time. Specifically, we ask whether it matters for how long countries have been sharing the common currency. Table 5 presents the results of estimating equation (2). The length of a country's membership in a currency union is important, as in both the world and Africa samples, we estimate that one additional year of membership increases trade by 1.4 and 2.0 percent, respectively. Therefore, in the world sample, after a country has been in a currency union for 10 years, the impact on trade would be a 15 percent increase $\left[(1+0.014)^{10}\right]$, which implies that for a currency union to achieve the Glick and Rose (2002) results (namely, double trade) countries have to "wait" for about 67 years. (For the Africa sample, after 10 years of currency union membership trade increases by an estimated 22 percent, and trade is estimated to take 45 years to double.) Furthermore, as Figures 1 and 2 show, there may be a nonlinear impact of leaving a currency union. Therefore, we add a quadratic term, $(\text { years } C U)_{i j}^{2}$, to equation (2). Columns 2 and 4 (and 6 and 8) of Table 5 show a negative (and significant) quadratic term which suggests some diminishing returns of currency union membership.

In order to investigate the effects of currency unions on the co-movements of prices and output we follow the approach of Alesina, Barro, and Tenreyro (2002), and Tenreyro and Barro (2003). We test whether their results hold in a bilateral approach to currency unions, especially in the context of Africa and estimate equation (1), sequentially substituting the dependent variable with $V P_{i j}$, and $V Y_{i j}$ as calculated in equations (4) and (6). ${ }^{34}$ The results of the estimated impact on co-movements of output and prices are presented in Table 6 , columns 1-4 and 5-8, respectively. For both the world and Africa samples, we find that currency unions tend to increase the co-movement of prices but that they are not systematically related to the co-movement of outputs. This also confirms the results of Alesina, Barro, and Tenreyro (2002) for the world sample. In addition, the marginal effect of

\footnotetext{
${ }^{33}$ This cannot be seen in the Glick and Rose data because plots of only 30 years after the dissolution of a currency union are used.

${ }^{34}$ We estimate the equations for the averages 1948-2003.
} 
currency unions on the price co-movements is higher for Africa. This is an important observation, as co-movements are lower in Africa (see summary statistics in Appendix C). The coefficient of currency union for Africa ( 0.04 with country fixed-effects) is quite high because mean co-movements of prices are equal to -0.15 for that subsample. The fact that the estimated coefficients on the currency union dummy variable are not significantly different from zero in the output co-movement regressions may arise because the theoretical link between currency union and output co-movement is ambiguous, and largely depends on the extend to which trade is intra or inter-industry. ${ }^{35}$ Also, the positive estimated effect of currency union on price co-movement may emerge because countries that are members of currency unions avoid the inflation and nominal exchange rate volatility that characterizes other regimes.

Finally, we examine whether participation in currency unions makes trade more stable by reducing exchange rate volatility. Table 7 shows estimations of the gravity model with the coefficient of variation of $\log$ of real trade as dependent variable. Columns 1 and 2 of Table 7 show that currency union does make trade more stable, with the marginal impact slightly higher in Africa than for in the world. However, once country-pair fixed-effects are taken into account (columns 3 and 4), for both the world and Africa samples the currency union coefficient falls and becomes statistically insignificant. Nevertheless, the currency union impact is high as the mean stability for Africa sample is 0.22 (compared to 0.18 for the world).

\section{Sensitivity analysis}

Similarly to the previous section, we check the robustness of the results presented in Tables 5,6 , and 7 , by conducting sensitivity checks of the specification: estimating the dependent variable as average of the logarithm of exports and imports; adding quadratic terms for output and output per capita to control for possible sample nonlinearities; and adding time effects. Estimates in Table 5 are robust to all the above sensitivity checks: after a country in the world (Africa) has been in a currency union for 10 years, trade increases by 14-22 percent (20-29 percent), and the diminishing returns of currency union membership effect is always significant. The conclusions of Tables 6 and 7 are also insensitive to the perturbations. In particular, for Table 7, we estimate the specification with other techniques and measures of stability. The results are reasonably robust, except in the specifications with zero-trade observations included (which can be explained by the fact that zeros for the extended period of time bias the stability measure). ${ }^{36}$

\footnotetext{
${ }^{35}$ As also discussed in Alesina, Barro, and Tenreyro (2002) increased interindustry trade may stimulate sectoral specialization and lead to less co-movements (as increased specialization likely lowers the co-movements of outputs and prices with industry-specific shocks would become country specific shocks), while intraindustry trade likely leads to more co-movements.

${ }^{36}$ These other methods used (described in the methodology section) include the maximal absolute value, the mean absolute value, and the standard deviation of the residual from a conventional gravity equation of exports in levels.
} 


\section{CONCLUSIONS}

This paper has provided some insights into several aspects of the performance of currency union using an augmented version of the gravity model and focusing on two samples, the world and Africa. First, we have confirmed the results that the impact of a currency union on trade is large: countries that belong to the same currency union trade about twice as much with each other compared with similar countries that do not share the same currency. Moreover, this increase in trade comes without trade diversion from non-currency-union members. Second, we have found that the duration of a country's membership in a currency union matters: the longer the duration the more the benefits, with some diminishing returns. Third, we have shown that currency union participation reduces trade volatility, increases price co-movements, but has no significant effect on output co-movements among members. Finally, these results are fairly robust to the estimation methodology employed and, although they hold true for both samples under investigation, the marginal effects and mechanisms of transmission may vary across the two samples.

Although this paper has concluded that several aspects of the performance of currency union operate more or less the same in Africa as elsewhere, the methodology herein does not constitute an explicit investigation into how trade and its underlying determinants are explicitly interconnected, or the extent to which currency unions can promote growth and poverty reduction. Identifying the similarities and some of the differences across the samples only begins to tackle the problem and may, in fact, raise more questions than it answers. More work is required in this direction. Perhaps one avenue might be to look for omitted factors that induce countries to join a currency union and to trade more, as suggested by Rose and van Wincoop (2001). Joining a currency union and opening up to the world are very often political decisions, so that such omitted factors may lie in a set of political and institutional variables. This is not a new realization: in recent papers on "deeper" determinants of economic growth, both institutions and trade openness determine a country's performance in the long run (see, for example, Acemoglu, Johnson, and Robinson, 2001; and Rodrik, Subramanian, and Trebbi, 2002). In the complicated web of relationships describing income, its determinants, and the linkages between the determinants, the interdependence of trade and institutions is a recurring theme that is difficult to handle, not least because of the issues of causality and construction of proper instruments. 

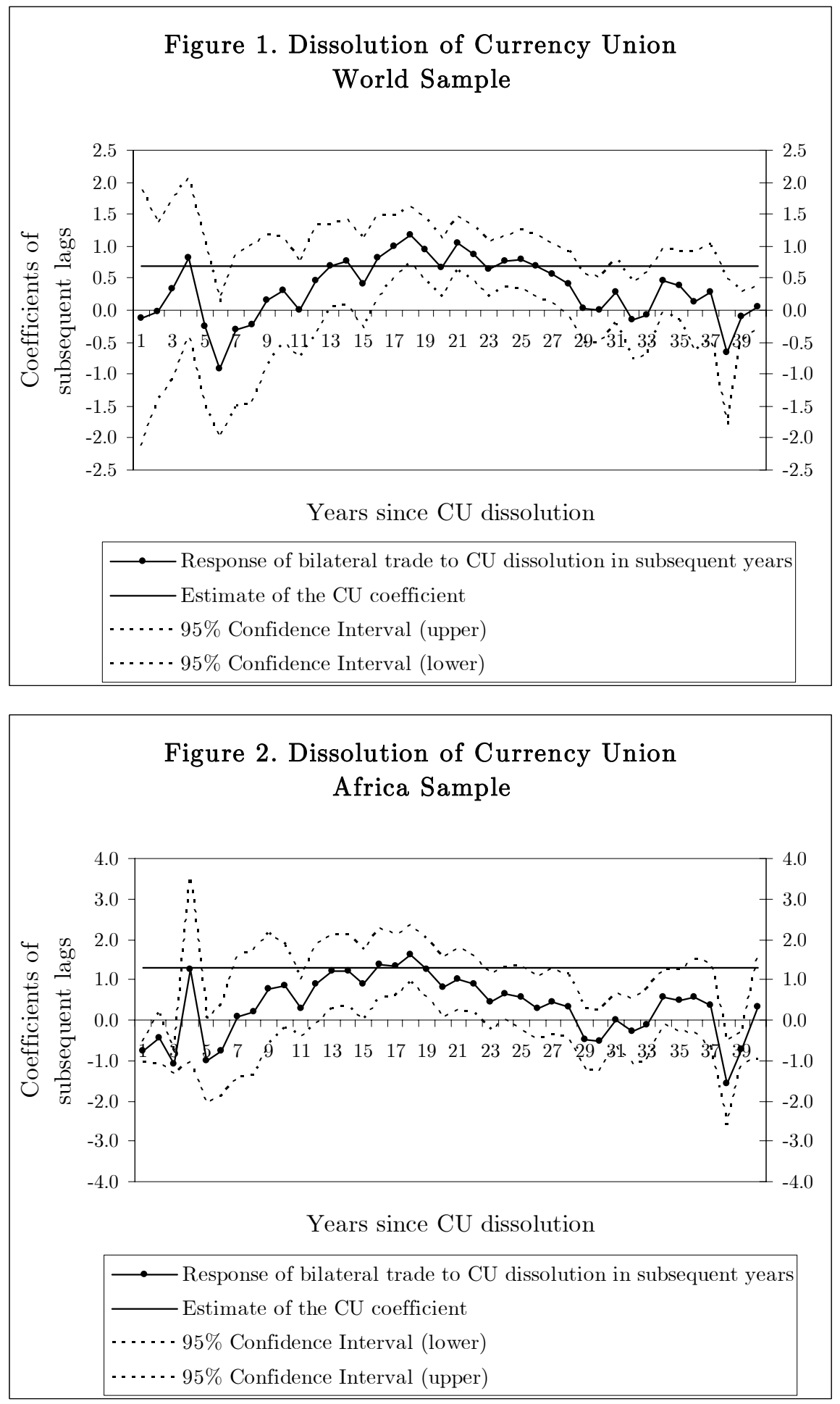

Notes:

1. The horizontal lines in Figures 1 and 2 correspond to the estimate of the coefficient of the currency union dummy (the g coefficient for the gravity equation (1) extended to include the vector of lagged variables described in the text) for the World and Africa samples, respectively.

2. The corresponding lag of the dummy variable associated with CU dissolution is statistically significant if the corresponding error bands exclude zero. 
Table 1: Benchmark Results

Dependent variable is $\log$ of real trade, $\log (\mathrm{Xij})$

\begin{tabular}{|c|c|c|c|c|c|c|}
\hline $\begin{array}{l}\text { Sample: } \\
\text { Estimation: } \\
\text { Specification: }\end{array}$ & $\begin{array}{c}\text { World } \\
\text { OLS } \\
(1) \\
\end{array}$ & $\begin{array}{c}\text { World } \\
\text { OLS } \\
(2) \\
\end{array}$ & $\begin{array}{c}\text { Africa } \\
\text { OLS } \\
(3) \\
\end{array}$ & $\begin{array}{c}\text { World } \\
\text { Fixed effects } \\
(4) \\
\end{array}$ & $\begin{array}{c}\text { World } \\
\text { Fixed effects } \\
(5) \\
\end{array}$ & $\begin{array}{c}\text { Africa } \\
\text { Fixed effects } \\
(6) \\
\end{array}$ \\
\hline Currency union & $\begin{array}{l}1.00^{* *} \\
(8.55)\end{array}$ & $\begin{array}{l}0.84^{* *} \\
(7.75)\end{array}$ & $\begin{array}{l}0.99^{* *} \\
(6.57)\end{array}$ & $\begin{array}{c}0.54^{* *} \\
(13.37)\end{array}$ & $\begin{array}{c}0.58^{* *} \\
(14.35)\end{array}$ & $\begin{array}{l}0.55^{* *} \\
(8.18)\end{array}$ \\
\hline Log distance & $\begin{array}{r}-1.08 * * \\
(52.68)\end{array}$ & $\begin{array}{l}-1.05 * * \\
(52.08)\end{array}$ & $\begin{array}{l}-1.06^{* *} \\
(19.77)\end{array}$ & & & \\
\hline Log product real GDP & $\begin{array}{r}0.92 \\
(104.20)\end{array}$ & $\begin{array}{r}0.93^{* *} \\
(105.38)\end{array}$ & $\begin{array}{r}1.01 \\
(61.62)\end{array}$ & $\begin{array}{c}0.16 \text { ** } \\
(24.28)\end{array}$ & $\begin{array}{c}0.15^{* *} \\
(22.52)\end{array}$ & $\begin{array}{l}-0.10 * * \\
(8.66)\end{array}$ \\
\hline Log product real GDP/capita & $\begin{array}{r}0.42^{* *} \\
(32.28)\end{array}$ & $\begin{array}{l}0.44 \text { ** } \\
(33.80)\end{array}$ & $\begin{array}{r}0.34 \text { ** } \\
(14.77)\end{array}$ & $\begin{array}{r}0.55^{* *} \\
-(51.62)\end{array}$ & $\begin{array}{r}0.57 \text { ** } \\
(53.47)\end{array}$ & $\begin{array}{l}0.66^{* *} \\
(33.23)\end{array}$ \\
\hline Common language & $\begin{array}{l}0.36 \text { ** } \\
(9.25)\end{array}$ & $\begin{array}{l}0.35 \text { ** } \\
(9.31)\end{array}$ & $\begin{array}{l}0.29 \text { ** } \\
(4.66)\end{array}$ & & & \\
\hline Common land border & $\begin{array}{l}0.52 \text { ** } \\
(4.71)\end{array}$ & $\begin{array}{c}0.40 \\
(3.85)\end{array}$ & $\begin{array}{l}1.22 \\
(7.30)\end{array}$ & & & \\
\hline FTA & $\begin{array}{l}1.14 \text { ** } \\
(10.40)\end{array}$ & & & $\begin{array}{c}0.64 \text { ** } \\
(18.75)\end{array}$ & & \\
\hline FTA (with Africa) & & $\begin{array}{r}1.19^{* *} \\
-14.32\end{array}$ & $\begin{array}{l}0.92 * * \\
-7.46\end{array}$ & & $\begin{array}{l}0.30 \text { ** } \\
(12.08)\end{array}$ & $\begin{array}{l}0.20 \\
(4.61)\end{array}$ \\
\hline Number landlocked in the pair & $\begin{array}{l}-0.23^{* *} \\
(8.17)\end{array}$ & $\begin{array}{l}-0.25^{* *} \\
(8.82)\end{array}$ & $\begin{array}{l}-0.35 * * \\
(8.86)\end{array}$ & & & \\
\hline Number islands in the pair & $\begin{array}{r}0.03 \\
(0.92)\end{array}$ & $\begin{array}{r}0.03 \\
(0.73)\end{array}$ & $\begin{array}{l}-0.31^{* *} \\
(5.00)\end{array}$ & & & \\
\hline Log product of areas & $\begin{array}{r}-0.08 \text { ** } \\
(10.75)\end{array}$ & $\begin{array}{r}-0.08 \text { ** } \\
(11.26)\end{array}$ & $\begin{array}{l}-0.18^{* *} \\
(14.70)\end{array}$ & & & \\
\hline Common colonizer & $\begin{array}{l}0.55^{* * *} \\
(8.78)\end{array}$ & $\begin{array}{l}0.51 \text { ** } \\
(8.27)\end{array}$ & $\begin{array}{l}0.30 \text { ** } \\
(3.48)\end{array}$ & & & \\
\hline Current colony & $\begin{array}{l}0.95 \\
(3.91)\end{array}$ & $\begin{array}{l}0.99 \text { ** } \\
(4.02)\end{array}$ & $\begin{array}{r}-0.39 \\
(0.86)\end{array}$ & $\begin{array}{r}0.43 \\
(5.42)\end{array}$ & $\begin{array}{l}0.41 \text { ** } \\
(5.11)\end{array}$ & $\begin{array}{r}-0.07 \\
(0.49)\end{array}$ \\
\hline Ever colony & $\begin{array}{r}1.31 \text { ** } \\
(10.75)\end{array}$ & $\begin{array}{c}1.32^{* *} \\
(10.97)\end{array}$ & $\begin{array}{r}2.14 \text { ** } \\
(14.42)\end{array}$ & & & \\
\hline Same nation & $\begin{array}{r}-0.20 \\
(0.20)\end{array}$ & $\begin{array}{r}-0.23 \\
(0.22)\end{array}$ & $\begin{array}{l}1.63 \text { ** } \\
(3.30)\end{array}$ & & & \\
\hline Observations & 265,262 & 265,262 & 100,597 & 265,262 & 265,262 & 100,597 \\
\hline R-squared (within) & & & & 0.13 & 0.13 & 0.03 \\
\hline R-squared (between) & & & & 0.41 & 0.40 & 0.01 \\
\hline R-squared (overall) & 0.68 & 0.68 & 0.52 & 0.38 & 0.36 & 0.01 \\
\hline Hausman test (p-value) & & & & 0.00 & 0.00 & 0.00 \\
\hline
\end{tabular}

Notes:

The table reports robust t-statistics in parentheses.

One asterisk $(*)$ denotes significance at the 5 percent level; two asterisks $(* *)$ denote significance at the 1 percent level. 
Table 2: Africa Trade Details

Dependent variable is $\log$ of real trade, $\log (\mathrm{Xij})$

\begin{tabular}{|c|c|c|c|c|c|c|}
\hline Sample: & World & Africa-ROW & Intra-Africa & World & Africa-ROW & Intra-Africa \\
\hline Estimation: & OLS & OLS & OLS & Fixed effects & Fixed effects & Fixed effects \\
\hline Specification: & $(1)$ & $(2)$ & $(3)$ & (4) & $(5)$ & (6) \\
\hline Currency union & $\begin{array}{l}0.799^{* *} \\
(7.03)\end{array}$ & $\begin{array}{r}0.53 \\
(1.18)\end{array}$ & $\begin{array}{l}0.55^{* *} \\
(2.69)\end{array}$ & $\begin{array}{l}0.58^{* *} \\
(14.35)\end{array}$ & $\begin{array}{l}0.62^{* *} \\
(4.56)\end{array}$ & $\begin{array}{l}0.53^{* *} \\
(6.35)\end{array}$ \\
\hline Africa-ROW & $\begin{array}{l}0.27 * * \\
(7.90)\end{array}$ & & & & & \\
\hline Intra Africa & $\begin{array}{l}0.42^{* *} \\
(4.58)\end{array}$ & & & & & \\
\hline Log distance & $\begin{array}{l}-1.06 \text { ** } \\
(52.00)\end{array}$ & $\begin{array}{l}-0.96 \text { ** } \\
(15.64)\end{array}$ & $\begin{array}{l}-1.29 * * \\
(9.92)\end{array}$ & & & \\
\hline Log product real GDP & $\begin{array}{r}0.94 \\
(104.26)\end{array}$ & $\begin{array}{c}1.06 \\
(64.47)\end{array}$ & $\begin{array}{r}0.62 \\
(9.83)\end{array}$ & $\begin{array}{c}0.15^{* *} \\
(22.52)\end{array}$ & $\begin{array}{l}-0.13^{* *} \\
(10.37)\end{array}$ & $\begin{array}{l}-0.07 * \\
(2.56)\end{array}$ \\
\hline Log product real GDP/capita & $\begin{array}{l}0.48 \text { ** } \\
(35.94)\end{array}$ & $\begin{array}{l}0.33^{* *} \\
(13.95)\end{array}$ & $\begin{array}{l}0.50 \text { ** } \\
(5.80)\end{array}$ & $\begin{array}{l}0.57 * * \\
(53.47)\end{array}$ & $\begin{array}{l}0.75 \\
(32.71)\end{array}$ & $\begin{array}{l}0.37 \\
(8.34)\end{array}$ \\
\hline Common language & $\begin{array}{l}0.33^{* *} \\
(8.76)\end{array}$ & $\begin{array}{l}0.27 * * \\
(4.26)\end{array}$ & $\begin{array}{l}0.40 * \\
(2.01)\end{array}$ & & & \\
\hline Common land border & $\begin{array}{l}0.43^{* *} \\
(4.17)\end{array}$ & $\begin{array}{l}1.10^{* *} \\
(3.21)\end{array}$ & $\begin{array}{l}0.98 \text { ** } \\
(4.27)\end{array}$ & & & \\
\hline FTA (with Africa) & $\begin{array}{l}1.15^{* *} \\
(13.08)\end{array}$ & & $\begin{array}{l}0.78 \text { ** } \\
(5.24)\end{array}$ & $\begin{array}{l}0.30 \\
(12.08)\end{array}$ & & $\begin{array}{l}0.18^{* *} \\
(3.39)\end{array}$ \\
\hline Number landlocked in the pair & $\begin{array}{l}-0.28 \text { ** } \\
(9.97)\end{array}$ & $\begin{array}{l}-0.37 * * \\
(8.82)\end{array}$ & $\begin{array}{l}-0.33^{* *} \\
(3.07)\end{array}$ & & & \\
\hline Number islands in the pair & $\begin{array}{r}0.04 \\
(1.09)\end{array}$ & $\begin{array}{l}-0.39 * * \\
(6.07)\end{array}$ & $\begin{array}{r}0.17 \\
(0.83)\end{array}$ & & & \\
\hline Log product of areas & $\begin{array}{l}-0.09 \\
(12.35)\end{array}$ & $\begin{array}{r}-0.20 \\
(16.14)\end{array}$ & $\begin{array}{r}-0.01 \\
(0.15)\end{array}$ & & & \\
\hline Common colonizer & $\begin{array}{l}0.49 \text { ** } \\
(7.91)\end{array}$ & $\begin{array}{l}0.32 \text { ** } \\
(3.46)\end{array}$ & $\begin{array}{r}0.25 \\
(1.09)\end{array}$ & & & \\
\hline Current colony & $\begin{array}{l}0.98 \text { ** } \\
(3.92)\end{array}$ & $\begin{array}{r}-0.03 \\
(0.06)\end{array}$ & & $\begin{array}{l}0.41 \text { ** } \\
(5.11)\end{array}$ & $\begin{array}{r}-0.10 \\
(0.65)\end{array}$ & \\
\hline Ever colony & $\begin{array}{l}1.30 \\
(11.25)\end{array}$ & $\begin{array}{r}2.12 \\
(14.08)\end{array}$ & & & & \\
\hline Same nation & $\begin{array}{r}-0.31 \\
(0.31)\end{array}$ & $\begin{array}{l}1.47 \text { ** } \\
(2.62)\end{array}$ & & & & \\
\hline$\overline{\text { Observations }}$ & 265,262 & 85,759 & 14,838 & 265,262 & 85,759 & 14,838 \\
\hline R-squared (within) & & & & 0.13 & 0.03 & 0.01 \\
\hline R-squared (between) & & & & 0.40 & 0.00 & 0.01 \\
\hline R-squared (overall) & 0.68 & 0.54 & 0.40 & 0.36 & 0.00 & 0.01 \\
\hline Hausman test (p-value) & & & & 0.00 & 0.00 & 0.00 \\
\hline
\end{tabular}

Notes:

The table reports robust t-statistics in parentheses.

One asterisk $(*)$ denotes significance at the 5 percent level; two asterisks $(* *)$ denote significance at the 1 percent level. 
Table 3: Trade Creation or Diversion? Dependent variable is $\log$ of real trade, $\log (\mathrm{Xij})$

\begin{tabular}{|c|c|c|c|c|c|c|c|c|}
\hline $\begin{array}{l}\text { Sample: } \\
\text { Estimation: } \\
\text { Specification: }\end{array}$ & $\begin{array}{c}\text { World } \\
\text { OLS } \\
(1) \\
\end{array}$ & $\begin{array}{c}\text { Africa } \\
\text { OLS } \\
(2) \\
\end{array}$ & $\begin{array}{c}\text { Africa-ROW } \\
\text { OLS } \\
(3) \\
\end{array}$ & $\begin{array}{c}\text { Intra-Africa } \\
\text { OLS } \\
(4) \\
\end{array}$ & $\begin{array}{c}\text { World } \\
\text { Fixed effects } \\
(5) \\
\end{array}$ & $\begin{array}{c}\text { Africa } \\
\text { Fixed effects } \\
(6) \\
\end{array}$ & $\begin{array}{c}\text { Africa-ROW } \\
\text { Fixed effects } \\
(7) \\
\end{array}$ & $\begin{array}{c}\text { Intra-Africa } \\
\text { Fixed effects } \\
(8)\end{array}$ \\
\hline Currency union & $\begin{array}{l}0.97 \text { ** } \\
(8.77)\end{array}$ & $\begin{array}{l}1.05^{* *} \\
(6.81)\end{array}$ & $\begin{array}{r}0.61 \\
(1.38)\end{array}$ & $\begin{array}{l}0.59 \text { ** } \\
(2.58)\end{array}$ & $\begin{array}{c}0.73^{* *} \\
(17.74)\end{array}$ & $\begin{array}{c}0.70 \\
(10.29)\end{array}$ & $\begin{array}{c}0.73^{* *} \\
(5.35)\end{array}$ & $\begin{array}{c}1.03 \\
(10.80)\end{array}$ \\
\hline Trade diversion & $\begin{array}{c}0.23^{* *} \\
(8.66)\end{array}$ & $\begin{array}{c}0.10 * \\
(2.35)\end{array}$ & $\begin{array}{r}0.09 \\
(1.92)\end{array}$ & $\begin{array}{r}0.09 \\
(0.55)\end{array}$ & $\begin{array}{c}0.21 \\
(21.18)\end{array}$ & $\begin{array}{c}0.18 \text { ** } \\
(10.24)\end{array}$ & $\begin{array}{l}0.12^{* *} \\
(6.71)\end{array}$ & $\begin{array}{r}0.58 \text { ** } \\
(10.75)\end{array}$ \\
\hline Log distance & $\begin{array}{l}-1.05^{* *} \\
(52.02)\end{array}$ & $\begin{array}{l}-1.05 \\
(19.62)\end{array}$ & $\begin{array}{l}-0.96^{* *} \\
(15.61)\end{array}$ & $\begin{array}{l}-1.29 \text { ** } \\
(9.86)\end{array}$ & & & & \\
\hline Log product real GDP & $\begin{array}{c}0.93^{* *} \\
(105.28)\end{array}$ & $\begin{array}{l}1.01 \\
(61.82)\end{array}$ & $\begin{array}{l}1.06^{* *} \\
(64.45)\end{array}$ & $\begin{array}{l}0.63 \text { ** } \\
(9.89)\end{array}$ & $\begin{array}{l}0.18 \text { ** } \\
(26.35)\end{array}$ & $\begin{array}{l}-0.06 \text { ** } \\
(5.35)\end{array}$ & $\begin{array}{l}-0.11 \text { ** } \\
(8.01)\end{array}$ & $\begin{array}{r}0.00 \\
(0.09)\end{array}$ \\
\hline Log product real GDP/capita & ${ }^{0.44} 4^{* *}$ & $\begin{array}{l}0.33 \text { ** } \\
(14.46)\end{array}$ & $\begin{array}{c}0.32 \\
(13.64)\end{array}$ & $\begin{array}{l}0.50 \text { ** } \\
(5.61)\end{array}$ & $\begin{array}{c}0.56^{* *} \\
(52.34)\end{array}$ & $\begin{array}{c}0.644^{\text {** }} \\
(31.95)\end{array}$ & $\begin{array}{c}0.73^{\text {** }} \\
(31.74)\end{array}$ & $\begin{array}{l}0.31 \\
(6.94)\end{array}$ \\
\hline Common language & $\begin{array}{l}0.33 \text { ** } \\
(8.80)\end{array}$ & $\begin{array}{l}0.28 \text { ** } \\
(4.57)\end{array}$ & $\begin{array}{r}0.27 \text { ** } \\
(4.20)\end{array}$ & $\begin{array}{l}0.40 * \\
(2.00)\end{array}$ & & & & \\
\hline Common land border & $\begin{array}{c}0.42^{* *} \\
(4.04)\end{array}$ & $\begin{array}{l}1.22 \text { ** } \\
(7.29)\end{array}$ & $\begin{array}{c}1.11 * * \\
(3.19)\end{array}$ & $\begin{array}{l}0.98 \text { ** } \\
(4.26)\end{array}$ & & & & \\
\hline FTA (with Africa) & $\begin{array}{c}1.17 \text { ** } \\
(14.03)\end{array}$ & $\begin{array}{l}0.93 \text { ** } \\
(7.55)\end{array}$ & & $\begin{array}{c}0.80 \\
(5.13)\end{array}$ & $\begin{array}{l}0.32 \text { ** } \\
(12.74)\end{array}$ & $\begin{array}{l}0.22 \\
(5.19)\end{array}$ & & $\begin{array}{l}0.31 \\
(5.61)\end{array}$ \\
\hline Number landlocked in the pair & $\begin{array}{l}-0.24 * * \\
(8.38)\end{array}$ & $\begin{array}{l}-0.35 \text { ** } \\
(8.71)\end{array}$ & $\begin{array}{l}-0.36 \text { ** } \\
(8.70)\end{array}$ & $\begin{array}{l}-0.33^{* *} \\
(3.03)\end{array}$ & & & & \\
\hline Number islands in the pair & $\begin{array}{r}0.01 \\
(0.24)\end{array}$ & $\begin{array}{l}-0.31 \text { ** } \\
(5.01)\end{array}$ & $\begin{array}{l}-0.39 \text { ** } \\
(6.07)\end{array}$ & $\begin{array}{r}0.17 \\
(0.86)\end{array}$ & & & & \\
\hline Log product of areas & $\begin{array}{l}-0.08^{* *} \\
(11.48)\end{array}$ & $\begin{array}{l}-0.18 \text { ** } \\
(14.82)\end{array}$ & $\begin{array}{l}-0.20^{* *} \\
(16.19)\end{array}$ & $\begin{array}{r}-0.01 \\
(0.20)\end{array}$ & & & & \\
\hline Common colonizer & $\begin{array}{c}0.52 \\
(8.42)\end{array}$ & $\begin{array}{l}0.31 \\
(3.60)\end{array}$ & $\begin{array}{l}0.33^{* *} \\
(3.51)\end{array}$ & $\begin{array}{r}0.26 \\
(1.15)\end{array}$ & & & & \\
\hline Current colony & $\begin{array}{l}1.03^{* *} \\
(4.17)\end{array}$ & $\begin{array}{l}-0.35 \\
(0.77)\end{array}$ & $\begin{array}{r}-0.02 \\
(0.03)\end{array}$ & & $\begin{array}{c}0.44 \\
(5.52)\end{array}$ & $\begin{array}{r}-0.08 \\
(0.53)\end{array}$ & $\begin{array}{r}-0.11 \\
(0.67)\end{array}$ & \\
\hline Ever colony & $\begin{array}{l}1.25 \\
(10.57)\end{array}$ & $\begin{array}{r}2.10 \\
(13.94)\end{array}$ & $\begin{array}{l}2.09 \\
(13.65)\end{array}$ & & & & & \\
\hline Same nation & $\begin{array}{r}-0.25 \\
(0.24)\end{array}$ & $\begin{array}{l}1.60 \text { ** } \\
(3.22)\end{array}$ & $\begin{array}{l}1.46 \text { ** } \\
(2.59)\end{array}$ & & & & & \\
\hline Observations & 265,262 & 100,597 & 85,759 & 14,838 & 265,262 & 100,597 & 85,759 & 14,838 \\
\hline R-squared (within) & & & & & 0.13 & 0.03 & 0.03 & 0.02 \\
\hline R-squared (between) & & & & & 0.13 & 0.02 & 0.03 & 0.02 \\
\hline R-squared (overall) & 0.68 & 0.52 & 0.54 & 0.40 & 0.43 & 0.03 & 0.00 & 0.04 \\
\hline Hausman test (p-value) & & & & & 0.39 & 0.00 & 0.00 & 0.04 \\
\hline
\end{tabular}

The table reports robust t-statistics in parentheses.

One asterisk $(*)$ denotes significance at the 5 percent level; two asterisks $\left({ }^{* *}\right)$ denote significance at the 1 percent level. 
Table 4: Sensitivity Analysis of Currency Union Effect

Various estimation methods

\begin{tabular}{|c|c|c|c|c|}
\hline \multirow[t]{2}{*}{ Sample: } & \multicolumn{2}{|c|}{ World } & \multicolumn{2}{|l|}{ Africa } \\
\hline & $\gamma$ & Effect & $\gamma$ & Effect \\
\hline Ordinary Least squares & $\begin{array}{l}0.84^{* *} \\
(7.75)\end{array}$ & 2.3 & $\begin{array}{l}0.99 \text { ** } \\
(6.57)\end{array}$ & 2.7 \\
\hline Dependent variable is $\log (100+\mathrm{Xij})$ & $\begin{array}{c}0.57^{* *} \\
(4.85)\end{array}$ & 1.8 & $\begin{array}{l}0.58^{* *} \\
(4.05)\end{array}$ & 1.8 \\
\hline Fixed Effects & $\begin{array}{c}0.58^{* *} \\
(14.35)\end{array}$ & 1.8 & $\begin{array}{l}0.55^{* *} \\
(8.18)\end{array}$ & 1.7 \\
\hline Fixed effects AND dependent variable calculated as average of logs & $\begin{array}{c}0.64 \\
(15.33)\end{array}$ & 1.9 & $\begin{array}{l}0.62 \text { ** } \\
(9.15)\end{array}$ & 1.9 \\
\hline Fixed effects AND non-linearities added & $\begin{array}{r}0.46^{* *} \\
(11.46)\end{array}$ & 1.6 & $\begin{array}{l}0.52^{* *} \\
(7.82)\end{array}$ & 1.7 \\
\hline Fixed effects AND time effects added & $\begin{array}{r}0.60 \\
(14.84)\end{array}$ & 1.8 & $\begin{array}{l}0.54^{* *} \\
(8.13)\end{array}$ & 1.7 \\
\hline Fixed effects AND dependent variable is $\log \left(100+X_{i j}\right)$ & $\begin{array}{l}0.16^{* *} \\
(4.55)\end{array}$ & 1.2 & $\begin{array}{r}0.03 \\
(0.59)\end{array}$ & 1.0 \\
\hline Tobit estimation & $\begin{array}{c}0.79 \text { ** } \\
(20.30)\end{array}$ & 2.2 & $\begin{array}{c}0.86 \text { ** } \\
(16.09)\end{array}$ & 2.4 \\
\hline County-fixed effects & $\begin{array}{c}0.85 \text { ** } \\
(7.86)\end{array}$ & 2.4 & $\begin{array}{c}1.14 \text { ** } \\
(7.82)\end{array}$ & 3.1 \\
\hline
\end{tabular}

Notes:

One asterisk $(*)$ denotes significance at the 5 percent level; two asterisks $\left({ }^{* *}\right)$ denote significance at the 1 percent level. Controls not reported are those listed in the other tables. 
Table 5: Duration of Currency Union Memebership Dependent variable is $\log$ of real trade, $\log (\mathrm{Xij})$

\begin{tabular}{|c|c|c|c|c|c|c|c|c|}
\hline Sample: & World & World & Africa & Africa & World & World & Africa & Africa \\
\hline Estimation: & OLS & OLS & OLS & OLS & Fixed effects & Fixed effects & Fixed effects & Fixed effects \\
\hline Specification: & $(1)$ & $(2)$ & $(3)$ & $(4)$ & $(5)$ & (6) & (7) & $(8)$ \\
\hline Years in currency union & $\begin{array}{c}c^{0.03} \text { ** } \\
(7.47)\end{array}$ & $\begin{array}{c}0.07^{* *} \\
(7.49)\end{array}$ & $\begin{array}{c}0.03 \text { ** } \\
(5.99)\end{array}$ & $\begin{array}{c}0.06 \text { ** } \\
(5.58)\end{array}$ & $\begin{array}{c}0.01 \text { ** } \\
(8.35)\end{array}$ & $\begin{array}{c}0.05^{* *} \\
(13.67)\end{array}$ & $\begin{array}{c}0^{0.02} \\
(8.71)\end{array}$ & $\begin{array}{c}0.04 \text { ** } \\
(8.05)\end{array}$ \\
\hline$(\text { Years in currency union })^{2}$ & & $\begin{array}{l}-0.001 \text { ** } \\
(4.86)\end{array}$ & & $\begin{array}{l}-0.001 \text { ** } \\
(3.26)\end{array}$ & & $\begin{array}{l}-0.001 \\
(11.00)\end{array}$ & & $\begin{array}{l}-0.001 \text { ** } \\
(4.58)\end{array}$ \\
\hline Log distance & $\begin{array}{c}-1.05^{* *} \\
(52.02)\end{array}$ & $\begin{array}{c}-1.05 \text { ** } \\
(52.00)\end{array}$ & $\begin{array}{c}-1.06 \text { ** } \\
(19.88)\end{array}$ & $\begin{array}{c}-1.06 \text { ** } \\
(19.82)\end{array}$ & & & & \\
\hline Log product real GDP & $\begin{array}{c}0.93 \\
(105.60)\end{array}$ & $\begin{array}{c}0.93^{* *} \\
(105.64)\end{array}$ & ${ }^{1.01}{ }^{* *}$ & ${ }^{1.01}$ ** & $\begin{array}{c}0.15 \text { ** } \\
(21.23)\end{array}$ & $\begin{array}{c}0.15^{* *} \\
(22.31)\end{array}$ & $\begin{array}{l}-0.11 \text { ** } \\
(9.91)\end{array}$ & $\begin{array}{l}-0.10 \text { ** } \\
(9.01)\end{array}$ \\
\hline Log product real GDP/capita & $\begin{array}{c}0.44^{* *} \\
(33.88)\end{array}$ & $\begin{array}{c}0.44^{* *} \\
(33.87)\end{array}$ & $\begin{array}{c}0.34 \\
(14.77)\end{array}$ & $\begin{array}{c}0.34 \\
(14.72)\end{array}$ & $\begin{array}{c}0.58^{* *} \\
(54.57)\end{array}$ & $\begin{array}{c}0.57 \\
(53.23)\end{array}$ & $\begin{array}{c}0.68 \text { ** } \\
(34.18)\end{array}$ & $\begin{array}{c}0.67 \\
(33.07)\end{array}$ \\
\hline Common language & $\begin{array}{c}0.35 \\
(9.26)\end{array}$ & $\begin{array}{c}0.35 \text { ** } \\
(9.22)\end{array}$ & $\begin{array}{c}0.29 \text { ** } \\
(4.74)\end{array}$ & $\begin{array}{c}0.29 \text { ** } \\
(4.67)\end{array}$ & & & & \\
\hline Common land border & $\begin{array}{l}0.41 \\
(3.94)\end{array}$ & $\begin{array}{l}0.40 \\
(3.89)\end{array}$ & $\begin{array}{l}1.23^{* *} \\
(7.29)\end{array}$ & $\begin{array}{l}1.23 \text { ** } \\
(7.29)\end{array}$ & & & & \\
\hline FTA (with Africa) & $\begin{array}{c}1.19 \text { ** } \\
(14.35)\end{array}$ & $\begin{array}{c}1.19^{* *} \\
(14.41)\end{array}$ & $\begin{array}{c}0.91 \text { ** } \\
(7.36)\end{array}$ & $\begin{array}{c}0.92 \\
(7.42)\end{array}$ & $\begin{array}{c}0.30^{* *} \\
(12.13)\end{array}$ & $\begin{array}{c}0.32 \text { ** } \\
(12.66)\end{array}$ & $\begin{array}{c}0.17 \text { ** } \\
(4.00)\end{array}$ & $\begin{array}{l}0.18 \text { ** } \\
(4.18)\end{array}$ \\
\hline Number landlocked in the pair & $\begin{array}{l}-0.25 \text { ** } \\
(8.82)\end{array}$ & $\begin{array}{l}-0.25 \text { ** } \\
(8.82)\end{array}$ & $\begin{array}{l}-0.36 \text { ** } \\
(8.90)\end{array}$ & $\begin{array}{l}-0.36 \text { ** } \\
(8.88)\end{array}$ & & & & \\
\hline Number islands in the pair & $\begin{array}{r}0.02 \\
(0.67)\end{array}$ & $\begin{array}{r}0.02 \\
(0.68)\end{array}$ & $\begin{array}{l}-0.31 * * \\
(5.00)\end{array}$ & $\begin{array}{l}-0.31 \text { ** } \\
(5.02)\end{array}$ & & & & \\
\hline Log product of areas & $\begin{array}{c}-0.08 \text { ** } \\
(11.30)\end{array}$ & $\begin{array}{c}-0.08 \text { ** } \\
(11.38)\end{array}$ & $\begin{array}{c}-0.18^{* *} \\
(14.67)\end{array}$ & $\begin{array}{c}-0.18 \text { ** } \\
(14.74)\end{array}$ & & & & \\
\hline Common colonizer & $\begin{array}{c}0.51 \text { ** } \\
(8.24)\end{array}$ & $\begin{array}{c}0.50 \text { ** } \\
(8.06)\end{array}$ & $\begin{array}{c}0.31 \text { ** } \\
(3.53)\end{array}$ & $\begin{array}{l}0.30 \\
(3.41)\end{array}$ & & & & \\
\hline Current colony & $\begin{array}{l}1.17 \\
(4.80)\end{array}$ & $\begin{array}{l}1.06 \\
(4.49)\end{array}$ & $\begin{array}{c}-0.04 \\
(0.09)\end{array}$ & $\begin{array}{r}-0.21 \\
(0.47)\end{array}$ & $\begin{array}{c}0.58^{* *} \\
(7.46)\end{array}$ & $\begin{array}{c}0.48 \text { ** } \\
(6.10)\end{array}$ & $\begin{array}{r}0.11 \\
(0.81)\end{array}$ & $\begin{array}{r}0.00 \\
(0.01)\end{array}$ \\
\hline Ever colony & $\begin{array}{c}1.34 \\
(11.10)\end{array}$ & $\begin{array}{c}1.33 \\
(11.04)\end{array}$ & $\begin{array}{c}2.15^{* *} \\
(14.69)\end{array}$ & $\begin{array}{c}2.14 \\
(14.60)\end{array}$ & & & & \\
\hline Same nation & $\begin{array}{l}-0.24 \\
(0.21)\end{array}$ & $\begin{array}{r}-0.22 \\
(0.19)\end{array}$ & $\begin{array}{l}1.62^{* *} \\
(3.23)\end{array}$ & $\begin{array}{l}1.73^{* *} \\
(3.60)\end{array}$ & & & & \\
\hline Observations & 265,262 & 265,262 & 100,597 & 100,597 & 265,262 & 265,262 & 100,597 & 100,597 \\
\hline R-squared (within) & & & & & 0.13 & 0.13 & 0.03 & 0.03 \\
\hline R-squared (between) & & & & & 0.38 & 0.40 & 0.00 & 0.01 \\
\hline R-squared (overall) & 0.68 & 0.68 & 0.52 & 0.52 & 0.35 & 0.36 & 0.01 & 0.01 \\
\hline Hausman test (p-value) & & & & & 0.00 & 0.00 & 0.00 & 0.00 \\
\hline
\end{tabular}

The table reports robust t-statistics in parentheses.

One asterisk $\left(^{*}\right)$ denotes significance at the 5 percent level; two asterisks $\left({ }^{*}\right)$ denote significance at the 1 percent level. 
Table 6: Currency Union Impact on Comovements of Outputs and Prices

Dependent variables: comovement of outputs (Vyij) for (1)-(4); and comovement of prices (Vpij) for (5)-(8)

\begin{tabular}{|c|c|c|c|c|c|c|c|c|}
\hline $\begin{array}{l}\text { Sample: } \\
\text { Specification: }\end{array}$ & $\begin{array}{c}\text { World } \\
(1)\end{array}$ & $\begin{array}{c}\text { Africa } \\
(2)\end{array}$ & $\begin{array}{c}\text { World } \\
(3) \\
\end{array}$ & $\begin{array}{c}\text { Africa } \\
(4)\end{array}$ & $\begin{array}{c}\text { World } \\
(5)\end{array}$ & $\begin{array}{c}\text { Africa } \\
(6)\end{array}$ & $\begin{array}{c}\text { World } \\
(7)\end{array}$ & $\begin{array}{c}\text { Africa } \\
(8)\end{array}$ \\
\hline Currency union & $\begin{array}{r}-0.002 \\
(0.61)\end{array}$ & $\begin{array}{r}0.002 \\
(0.55)\end{array}$ & $\begin{array}{r}0.000 \\
(0.12)\end{array}$ & $\begin{array}{r}0.000 \\
(0.25)\end{array}$ & $\begin{array}{l}0.06^{* *} \\
(9.07)\end{array}$ & $\begin{array}{l}0.07^{* *} \\
(9.35)\end{array}$ & $\begin{array}{r}0.03 \\
(11.19)\end{array}$ & $\begin{array}{l}0.04 \text { ** } \\
(11.19)\end{array}$ \\
\hline Log distance & $\begin{array}{l}0.002 \text { ** } \\
(3.56)\end{array}$ & $\begin{array}{l}0.008^{* *} \\
(7.58)\end{array}$ & $\begin{array}{l}-0.001 * * \\
(3.56)\end{array}$ & $\begin{array}{r}-0.001 \\
(0.96)\end{array}$ & $\begin{array}{r}-0.003 \\
(1.79)\end{array}$ & $\begin{array}{r}0.001 \\
(0.26)\end{array}$ & $\begin{array}{l}-0.004 \text { ** } \\
(5.33)\end{array}$ & $\begin{array}{l}-0.003 * \\
(2.23)\end{array}$ \\
\hline Log product real GDP & $\begin{array}{l}0.005 \\
(22.10)\end{array}$ & $\begin{array}{l}0.005^{* *} \\
(14.19)\end{array}$ & $\begin{array}{l}0.003 \text { ** } \\
(5.21)\end{array}$ & $\begin{array}{r}0.000 \\
(0.30)\end{array}$ & $\begin{array}{l}0.002 \text { ** } \\
(4.18)\end{array}$ & $\begin{array}{l}-0.003 \text { ** } \\
(3.96)\end{array}$ & $\begin{array}{l}0.007 \text { ** } \\
(3.34)\end{array}$ & $\begin{array}{l}-0.008 \text { ** } \\
(3.57)\end{array}$ \\
\hline Log product real GDP/capita & $\begin{array}{l}0.005 \text { ** } \\
(16.98)\end{array}$ & $\begin{array}{r}0.001 \\
(1.63)\end{array}$ & $\begin{array}{l}-0.004 \text { ** } \\
(4.39)\end{array}$ & $\begin{array}{r}0.001 \\
(0.56)\end{array}$ & $\begin{array}{c}0.012 \\
(14.76)\end{array}$ & $\begin{array}{c}0.016^{* *} \\
(16.61)\end{array}$ & $\begin{array}{r}-0.004 \\
(1.17)\end{array}$ & $\begin{array}{l}0.011 \text { ** } \\
(3.47)\end{array}$ \\
\hline Common language & $\begin{array}{r}0.001 \\
(0.65)\end{array}$ & $\begin{array}{r}-0.002 \\
(1.54)\end{array}$ & $\begin{array}{l}0.001 * \\
(2.05)\end{array}$ & $\begin{array}{r}0.000 \\
(0.13)\end{array}$ & $\begin{array}{r}0.001 \\
(0.42)\end{array}$ & $\begin{array}{r}0.000 \\
(0.09)\end{array}$ & $\begin{array}{r}0.002 \\
(1.43)\end{array}$ & $\begin{array}{r}0.001 \\
(1.15)\end{array}$ \\
\hline Common land border & $\begin{array}{l}0.006 * \\
(2.52)\end{array}$ & $\begin{array}{r}0.005 \\
(1.44)\end{array}$ & $\begin{array}{l}0.003 \text { ** } \\
(3.65)\end{array}$ & $\begin{array}{r}0.001 \\
(0.82)\end{array}$ & $\begin{array}{r}-0.005 \\
(0.66)\end{array}$ & $\begin{array}{r}-0.007 \\
(0.77)\end{array}$ & $\begin{array}{r}0.004 \\
(1.46)\end{array}$ & $\begin{array}{r}0.004 \\
(1.24)\end{array}$ \\
\hline FTA (with Africa) & $\begin{array}{l}0.012 \text { ** } \\
(4.59)\end{array}$ & $\begin{array}{l}0.010^{* *} \\
(2.65)\end{array}$ & $\begin{array}{l}0.003 * \\
(2.35)\end{array}$ & $\begin{array}{r}-0.001 \\
(0.60)\end{array}$ & $\begin{array}{l}0.018 * * \\
(2.84)\end{array}$ & $\begin{array}{r}0.015 \\
(1.89)\end{array}$ & $\begin{array}{l}0.007 * \\
(2.50)\end{array}$ & $\begin{array}{c}-0.007 * \\
(2.21)\end{array}$ \\
\hline Number landlocked in the pair & $\begin{array}{l}0.005 * * \\
(8.19)\end{array}$ & $\begin{array}{l}0.007 \text { ** } \\
(8.65)\end{array}$ & & & $\begin{array}{l}0.007 * * \\
(3.88)\end{array}$ & $\begin{array}{l}0.014 \text { ** } \\
(7.30)\end{array}$ & & \\
\hline Number islands in the pair & $\begin{array}{l}0.005 \text { ** } \\
(7.14)\end{array}$ & $\begin{array}{l}0.010^{* *} \\
(8.08)\end{array}$ & & & $\begin{array}{l}0.012 * * \\
(6.77)\end{array}$ & $\begin{array}{l}0.012 \text { ** } \\
(5.45)\end{array}$ & & \\
\hline Log product of areas & $\begin{array}{l}0.000 \text { ** } \\
(3.07)\end{array}$ & $\begin{array}{r}0.000 \\
(0.66)\end{array}$ & & & $\begin{array}{l}-0.004 * * \\
(9.62)\end{array}$ & $\begin{array}{r}-0.001 \\
(1.94)\end{array}$ & & \\
\hline Common colonizer & $\begin{array}{l}0.004^{* *} \\
(3.14)\end{array}$ & $\begin{array}{l}0.009 \text { ** } \\
(5.45)\end{array}$ & $\begin{array}{l}0.002 \text { ** } \\
(3.49)\end{array}$ & $\begin{array}{r}0.001 \\
(0.98)\end{array}$ & $\begin{array}{l}0.010 * * \\
(3.35)\end{array}$ & $\begin{array}{r}0.002 \\
(0.50)\end{array}$ & $\begin{array}{l}0.005 \text { ** } \\
(4.06)\end{array}$ & $\begin{array}{l}0.006 \text { ** } \\
(4.48)\end{array}$ \\
\hline Current colony & $\begin{array}{r}-0.018 \\
(1.70)\end{array}$ & $\begin{array}{c}-0.044 \\
(1.47)\end{array}$ & $\begin{array}{l}-0.007 * \\
(2.03)\end{array}$ & $\begin{array}{r}-0.002 \\
(0.23)\end{array}$ & $\begin{array}{r}0.049 \\
(1.90)\end{array}$ & $\begin{array}{r}-0.040 \\
(0.68)\end{array}$ & $\begin{array}{l}0.025 * \\
(2.15)\end{array}$ & $\begin{array}{l}-0.020 \\
(0.70)\end{array}$ \\
\hline Ever colony & $\begin{array}{c}0.004 \\
(1.70)\end{array}$ & $\begin{array}{l}0.018 * \\
(2.01)\end{array}$ & $\begin{array}{r}0.000 \\
(0.03)\end{array}$ & $\begin{array}{r}0.001 \\
(0.55)\end{array}$ & $\begin{array}{r}0.007 \\
(0.72)\end{array}$ & $\begin{array}{r}0.034 \\
(1.77)\end{array}$ & $\begin{array}{r}-0.006 \\
(1.40)\end{array}$ & $\begin{array}{r}0.005 \\
(0.70)\end{array}$ \\
\hline Same nation & & & & & & & & \\
\hline Country fixed effects & No & No & Yes & Yes & No & No & Yes & Yes \\
\hline Observations & 6,992 & 3,793 & 6,992 & 3,793 & 7,000 & 3,796 & 7,000 & 3,796 \\
\hline R-squared & 0.25 & 0.15 & 0.92 & 0.92 & 0.12 & 0.13 & 0.87 & 0.91 \\
\hline
\end{tabular}

Notes:

The table reports robust t-statistics in parentheses.

One asterisk $\left(^{*}\right)$ denotes significance at the 5 percent level; two asterisks $\left(^{* *}\right)$ denote significance at the 1 percent level. 
Table 7: Currency Union Impact on Trade Stability Dependent variable is trade variability, the coefficient of variation of $\log (\mathrm{Xij})$

\begin{tabular}{|c|c|c|c|c|}
\hline $\begin{array}{l}\text { Sample: } \\
\text { Estimation: } \\
\text { Specification: }\end{array}$ & $\begin{array}{c}\text { World } \\
\text { OLS } \\
(1) \\
\end{array}$ & $\begin{array}{c}\text { Africa } \\
\text { OLS } \\
(2) \\
\end{array}$ & $\begin{array}{c}\text { World } \\
\text { Panel fixed } \\
(3) \\
\end{array}$ & $\begin{array}{c}\text { Africa } \\
\text { Panel fixed } \\
(4) \\
\end{array}$ \\
\hline Currency union & $\begin{array}{l}-0.05^{* *} \\
(4.36)\end{array}$ & $\begin{array}{l}-0.06^{* *} \\
(4.40)\end{array}$ & $\begin{array}{r}-0.02 \\
(0.95)\end{array}$ & $\begin{array}{r}-0.02 \\
(0.64)\end{array}$ \\
\hline Log distance & $\begin{array}{c}0.05 \text { ** } \\
(22.53)\end{array}$ & $\begin{array}{r}0.07 \text { ** } \\
(13.09)\end{array}$ & & \\
\hline Log product real GDP & $\begin{array}{c}-0.03 \text { ** } \\
(30.40)\end{array}$ & $\begin{array}{l}-0.05^{* *} \\
(19.77)\end{array}$ & $\begin{array}{l}-0.01 * \\
(2.00)\end{array}$ & $\begin{array}{l}0.03 \text { ** } \\
(2.63)\end{array}$ \\
\hline Log product real GDP/capita & $\begin{array}{l}-0.02 \text { ** } \\
(9.86)\end{array}$ & $\begin{array}{l}-0.02 \text { ** } \\
(4.08)\end{array}$ & $\begin{array}{l}-0.04 \text { ** } \\
(6.11)\end{array}$ & $\begin{array}{l}-0.08 * * \\
(6.85)\end{array}$ \\
\hline Common language & $\begin{array}{l}-0.02^{* *} \\
(5.46)\end{array}$ & $\begin{array}{l}-0.03 \text { ** } \\
(3.55)\end{array}$ & & \\
\hline Common land border & $\begin{array}{c}0.02 \\
(2.01)\end{array}$ & $\begin{array}{l}-0.03 * \\
(2.41)\end{array}$ & & \\
\hline FTA (with Africa) & $\begin{array}{l}-0.06 \text { ** } \\
(6.30)\end{array}$ & $\begin{array}{l}-0.07 * * \\
(4.97)\end{array}$ & $\begin{array}{r}-0.02 \\
(1.46)\end{array}$ & $\begin{array}{l}-0.04 * \\
(2.31)\end{array}$ \\
\hline Number landlocked in the pair & $\begin{array}{r}0.01 \\
(1.83)\end{array}$ & $\begin{array}{r}0.02 * \\
(2.46)\end{array}$ & & \\
\hline Number islands in the pair & $\begin{array}{l}0.01 \\
(2.51)\end{array}$ & $\begin{array}{l}0.04 \\
(4.90)\end{array}$ & & \\
\hline Log product of areas & $\begin{array}{l}0.00^{* *} \\
(2.77)\end{array}$ & $\begin{array}{l}0.01 \text { ** } \\
(5.58)\end{array}$ & & \\
\hline Common colonizer & $\begin{array}{l}-0.02 \\
(2.15)\end{array}$ & $\begin{array}{r}0.00 \\
(0.21)\end{array}$ & & \\
\hline Current colony & $\begin{array}{r}-0.01 \\
(0.47)\end{array}$ & $\begin{array}{l}0.11 \text { ** } \\
(3.44)\end{array}$ & $\begin{array}{r}0.04 \\
(1.29)\end{array}$ & $\begin{array}{r}0.06 \\
(1.24)\end{array}$ \\
\hline Ever colony & $\begin{array}{l}-0.02 * \\
(2.55)\end{array}$ & $\begin{array}{l}-0.04 \text { ** } \\
(2.65)\end{array}$ & & \\
\hline Same nation & $\begin{array}{r}-0.03 \\
(1.00)\end{array}$ & $\begin{array}{l}-0.12 \text { ** } \\
(4.10)\end{array}$ & & \\
\hline Observations & 18,156 & 7,845 & 18,156 & 7,845 \\
\hline R-squared (within) & & & 0.05 & 0.10 \\
\hline R-squared (between) & & & 0.06 & 0.11 \\
\hline R-squared (overall) & 0.18 & 0.17 & 0.11 & 0.01 \\
\hline Hausman test ( $\mathrm{p}$-value) & & & 0.11 & 0.00 \\
\hline
\end{tabular}

Notes:

The table reports robust t-statistics in parentheses.

One asterisk $(*)$ denotes significance at the 5 percent level; two asterisks $(* *)$ denote significance at the 1 percent level. 


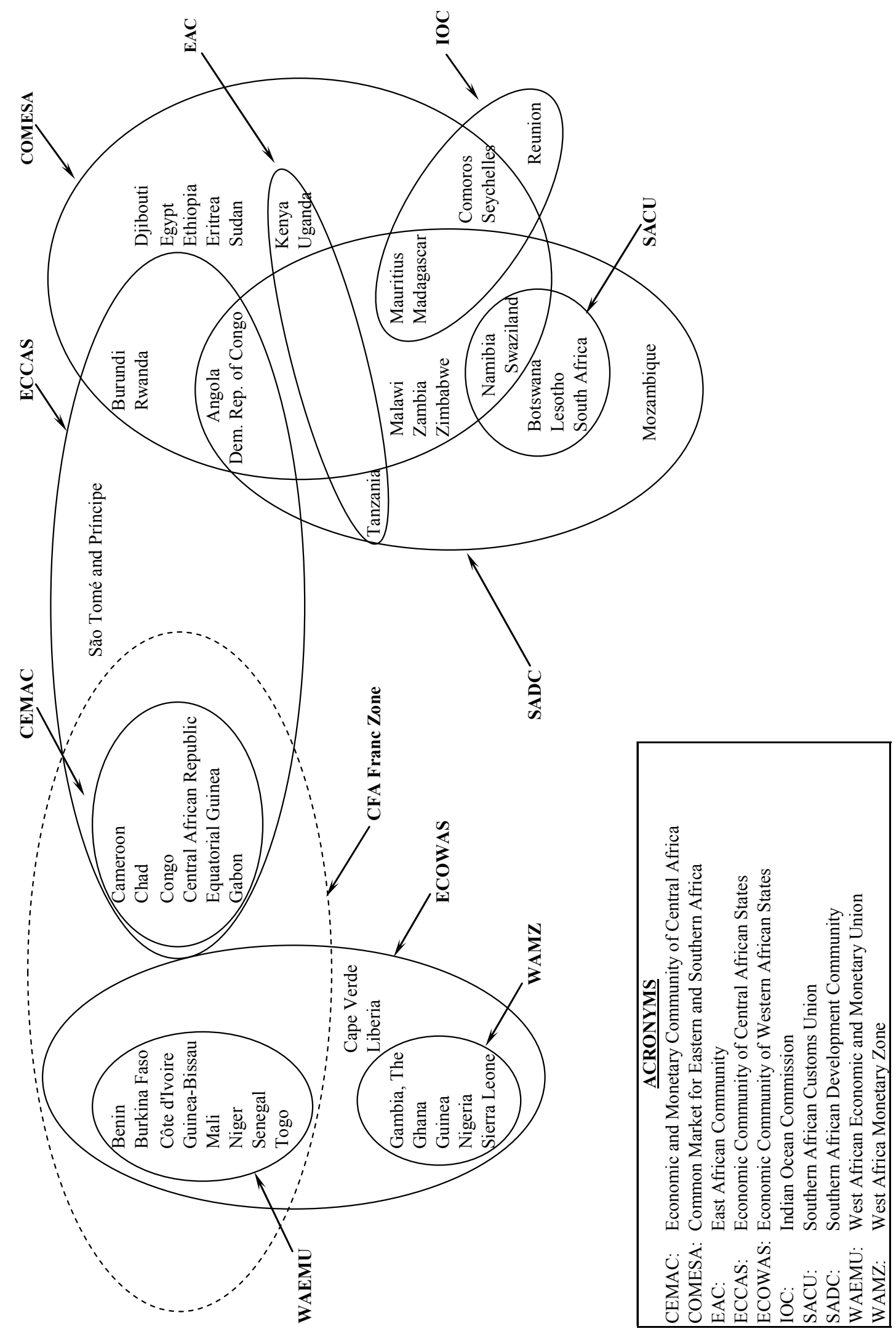




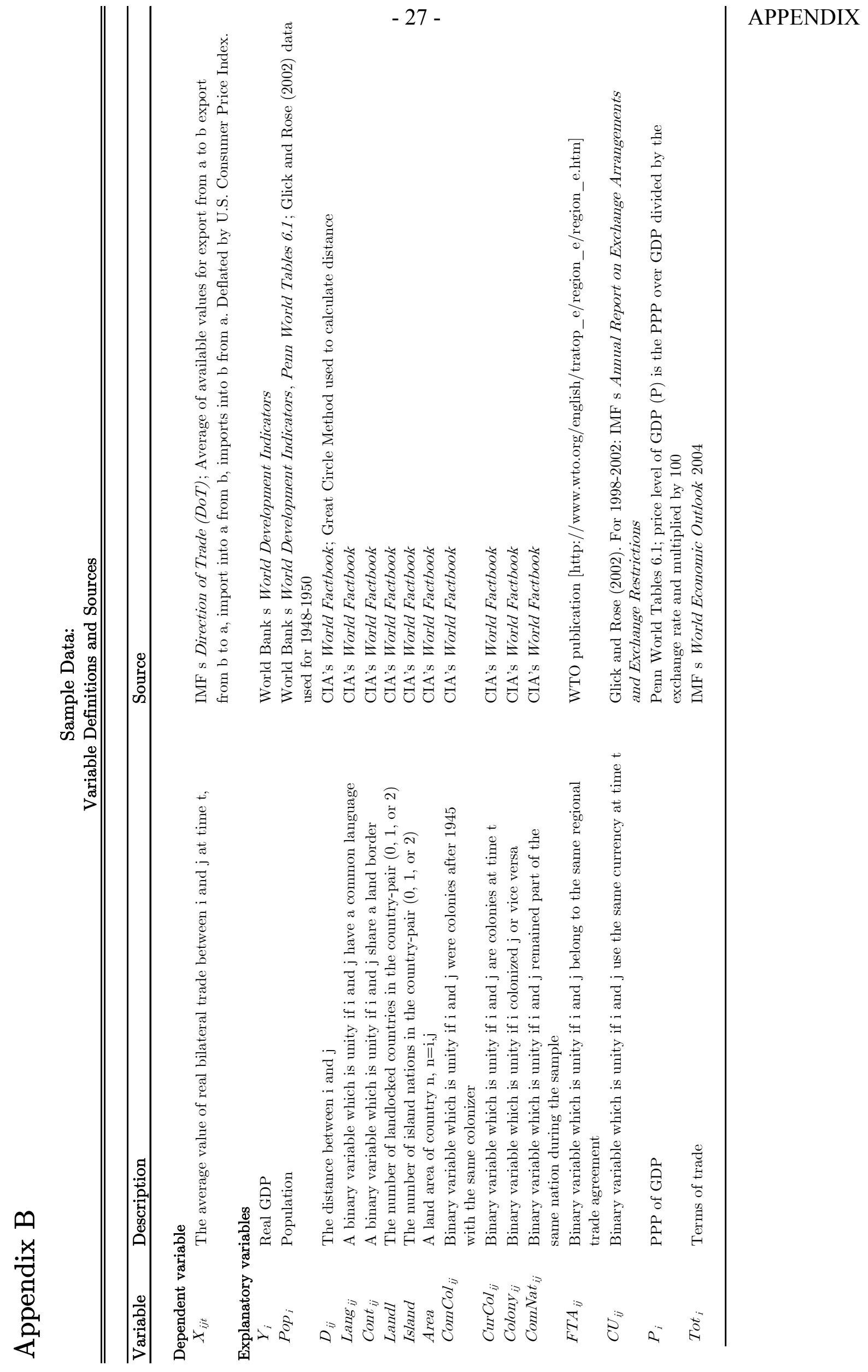




\section{Appendix C}

Table C1: Summary Statistics

\begin{tabular}{|c|c|c|c|c|}
\hline \multirow[b]{2}{*}{ Variable } & \multicolumn{2}{|c|}{$\begin{array}{c}\text { World sample } \\
(265,262 \text { observations })\end{array}$} & \multicolumn{2}{|c|}{$\begin{array}{c}\text { Africa sample } \\
(100,597 \text { observations })\end{array}$} \\
\hline & Mean & Std. Deviation & Mean & Std. Deviation \\
\hline Log of real trade & 10.020 & 3.246 & 8.813 & 2.951 \\
\hline Currency union & 0.014 & 0.119 & 0.027 & 0.161 \\
\hline Log distance & 8.167 & 0.809 & 8.175 & 0.661 \\
\hline Log product real GDP & 47.974 & 2.662 & 47.075 & 2.193 \\
\hline Log product real GDP/capita & 16.106 & 1.470 & 15.180 & 1.259 \\
\hline Common language & 0.216 & 0.411 & 0.266 & 0.442 \\
\hline Common land border & 0.030 & 0.170 & 0.029 & 0.169 \\
\hline FTA (with Africa) & 0.034 & 0.180 & 0.045 & 0.207 \\
\hline Number landlocked in the pair & 0.262 & 0.479 & 0.402 & 0.553 \\
\hline Number islands in the pair & 0.338 & 0.537 & 0.250 & 0.470 \\
\hline Log product of areas & 24.139 & 3.299 & 24.670 & 2.904 \\
\hline Common colonizer & 0.099 & 0.298 & 0.155 & 0.362 \\
\hline Current colony & 0.002 & 0.041 & 0.002 & 0.043 \\
\hline Ever colony & 0.020 & 0.139 & 0.017 & 0.129 \\
\hline Same nation & 0.000 & 0.016 & 0.000 & 0.017 \\
\hline Years in currency union & 0.359 & 3.481 & 0.705 & 4.840 \\
\hline Comovements of outputs ${ }^{1}$ & -0.075 & 0.030 & -0.087 & 0.031 \\
\hline Comovements of prices ${ }^{1}$ & -0.155 & 0.080 & -0.163 & 0.070 \\
\hline Trade volatility $^{2}$ & 0.181 & 0.258 & 0.224 & 0.294 \\
\hline
\end{tabular}

Notes:

${ }^{1}$ One value for country pair (6992/7000 observations for the world for co-movements of outputs/prices and 3,793/3,796 for Africa samples, respectively).

${ }^{2}$ Two values for country pair (18,156 observations for the world and 7,845 for the Africa sample) 


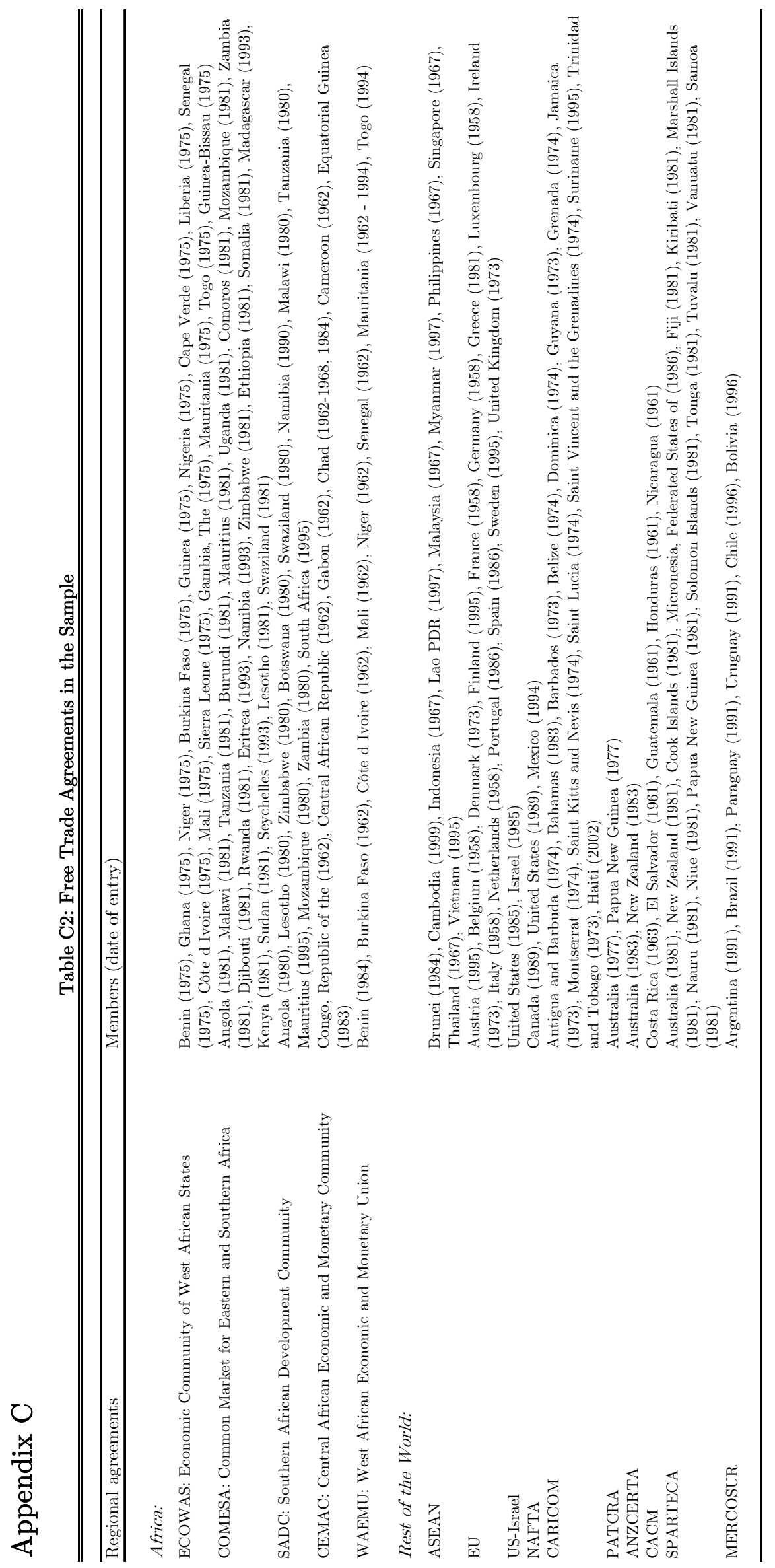


Table C3: Currency Unions in the Sample

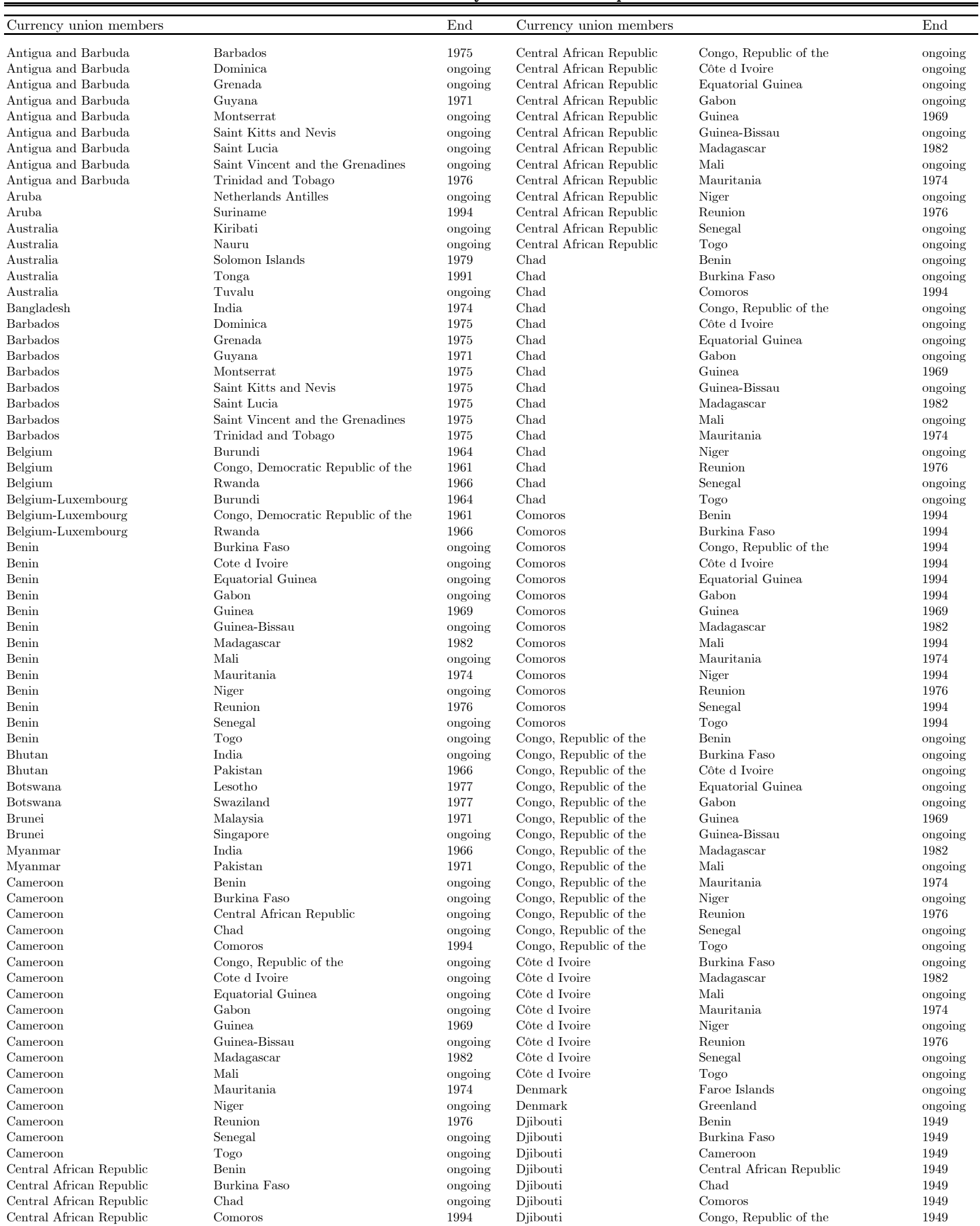


Table C3 (continued)

\begin{tabular}{|c|c|c|c|c|c|}
\hline Currency union members & & End & Currency union members & & End \\
\hline Djibouti & Côte d Ivoire & 1949 & Guyana & Trinidad and Tobago & 1971 \\
\hline Djibouti & Gabon & 1949 & India & Maldives & 1966 \\
\hline Djibouti & Guinea & 1949 & India & Mauritius & 1966 \\
\hline Djibouti & Madagascar & 1949 & India & Pakistan & 1966 \\
\hline Djibouti & Mali & 1949 & India & Seychelles & 1966 \\
\hline Djibouti & Mauritania & 1949 & Kenya & Somalia & 1971 \\
\hline Djibouti & Niger & 1949 & Kenya & Tanzania & 1978 \\
\hline Djibouti & Reunion & 1949 & Kenya & Uganda & 1978 \\
\hline Djibouti & Senegal & 1949 & Kuwait & India & 1961 \\
\hline Djibouti & Togo & 1949 & Lesotho & Swaziland & ongoing \\
\hline Dominica & Grenada & ongoing & Madagascar & Burkina Faso & 1982 \\
\hline Dominica & Guyana & 1971 & Madagascar & Mali & 1960 \\
\hline Dominica & Montserrat & ongoing & Madagascar & Mauritania & 1974 \\
\hline Dominica & Saint Kitts and Nevis & ongoing & Madagascar & Niger & 1982 \\
\hline Dominica & Saint Lucia & ongoing & Madagascar & Reunion & 1976 \\
\hline Dominica & Saint Vincent and the Grenadines & ongoing & Madagascar & Senegal & 1982 \\
\hline Dominica & Trinidad and Tobago & 1976 & Madagascar & Togo & 1982 \\
\hline Equatorial Guinea & Burkina Faso & ongoing & Malawi & Zambia & 1967 \\
\hline Equatorial Guinea & Cote d Ivoire & ongoing & Malawi & Zimbabwe & 1967 \\
\hline Equatorial Guinea & Gabon & ongoing & Malaysia & Singapore & 1971 \\
\hline Equatorial Guinea & Guinea-Bissau & ongoing & Maldives & Mauritius & 1967 \\
\hline Equatorial Guinea & Mali & ongoing & Maldives & Pakistan & 1971 \\
\hline Equatorial Guinea & Niger & ongoing & Mali & Burkina Faso & ongoing \\
\hline Equatorial Guinea & Senegal & ongoing & Mali & Mauritania & 1974 \\
\hline Equatorial Guinea & Togo & ongoing & Mali & Niger & ongoing \\
\hline France & Algeria & 1969 & Mali & Reunion & 1976 \\
\hline France & French Guiana & ongoing & Mali & Senegal & ongoing \\
\hline France & Guadeloupe & ongoing & Mali & Togo & ongoing \\
\hline France & Martinique & ongoing & Mauritania & Burkina Faso & 1974 \\
\hline France & Morocco & 1959 & Mauritania & Niger & 1974 \\
\hline France & Reunion & ongoing & Mauritania & Reunion & 1974 \\
\hline France & Saint Pierre and Miquelon & ongoing & Mauritania & Senegal & 1974 \\
\hline France & Tunisia & 1958 & Mauritania & Togo & 1974 \\
\hline Gabon & Burkina Faso & ongoing & Mauritius & Seychelles & 1976 \\
\hline Gabon & Côte d Ivoire & ongoing & Montserrat & Saint Kitts and Nevis & ongoing \\
\hline Gabon & Guinea & 1969 & Montserrat & Saint Lucia & ongoing \\
\hline Gabon & Guinea-Bissau & ongoing & Montserrat & Saint Vincent and the Grenadines & ongoing \\
\hline Gabon & Madagascar & 1982 & Montserrat & Trinidad and Tobago & 1976 \\
\hline Gabon & Mali & ongoing & Netherlands Antilles & Suriname & 1994 \\
\hline Gabon & Mauritania & 1974 & New Caledonia & French Polynesia & ongoing \\
\hline Gabon & Niger & ongoing & New Caledonia & Vanuatu & 1971 \\
\hline Gabon & Reunion & 1976 & New Caledonia & Wallis and Futuna & ongoing \\
\hline Gabon & Senegal & ongoing & New Zealand & Samoa & 1967 \\
\hline Gabon & Togo & ongoing & Niger & Burkina Faso & ongoing \\
\hline Gambia, The & Ghana & 1965 & Niger & Reunion & 1976 \\
\hline Gambia, The & Nigeria & 1967 & Niger & Senegal & ongoing \\
\hline Gambia, The & Sierra Leone & 1965 & Niger & Togo & ongoing \\
\hline Ghana & Nigeria & 1965 & Nigeria & Sierra Leone & 1965 \\
\hline Ghana & Sierra Leone & 1965 & Oman & India & 1970 \\
\hline Grenada & Guyana & 1971 & Pakistan & Mauritius & 1967 \\
\hline Grenada & Montserrat & ongoing & Pakistan & Seychelles & 1967 \\
\hline Grenada & Saint Kitts and Nevis & ongoing & Portugal & Angola & 1976 \\
\hline Grenada & Saint Lucia & ongoing & Portugal & Cape Verde & 1977 \\
\hline Grenada & Saint Vincent and the Grenadines & ongoing & Portugal & Guinea-Bissau & 1977 \\
\hline Grenada & Trinidad and Tobago & 1976 & Portugal & Mozambique & 1977 \\
\hline Guinea & Burkina Faso & 1969 & Portugal & São Tomé and Príncipe & 1977 \\
\hline Guinea & Côte d Ivoire & 1969 & Qatar & India & 1966 \\
\hline Guinea & Madagascar & 1969 & Qatar & United Arab Emirates & ongoing \\
\hline Guinea & Mali & 1969 & Reunion & Burkina Faso & 1976 \\
\hline Guinea & Mauritania & 1969 & Reunion & Senegal & 1976 \\
\hline Guinea & Niger & 1969 & Reunion & Togo & 1976 \\
\hline Guinea & Reunion & 1969 & Senegal & Burkina Faso & ongoing \\
\hline Guinea & Senegal & 1969 & Senegal & Togo & ongoing \\
\hline Guinea & Togo & 1969 & Somalia & Tanzania & 1971 \\
\hline Guinea-Bissau & Burkina Faso & ongoing & Somalia & Uganda & 1971 \\
\hline Guinea-Bissau & Côte d Ivoire & ongoing & South Africa & Botswana & 1977 \\
\hline Guinea-Bissau & Mali & ongoing & South Africa & Lesotho & ongoing \\
\hline Guinea-Bissau & Niger & ongoing & South Africa & Swaziland & ongoing \\
\hline Guinea-Bissau & Senegal & ongoing & Spain & Equatorial Guinea & 1969 \\
\hline Guinea-Bissau & Togo & ongoing & Sri Lanka & India & 1966 \\
\hline Guyana & Montserrat & 1971 & Sri Lanka & Pakistan & 1967 \\
\hline Guyana & Saint Kitts and Nevis & 1971 & Saint Kitts and Nevis & Saint Lucia & ongoing \\
\hline Guyana & Saint Lucia & 1971 & Saint Kitts and Nevis & Saint Vincent and the Grenadines & ongoing \\
\hline Guyana & Saint Vincent and the Grenadines & 1971 & Saint Kitts and Nevis & Trinidad and Tobago & 1976 \\
\hline
\end{tabular}


Table C3 (concluded)

\begin{tabular}{|c|c|c|c|c|c|}
\hline Currency union members & & End & Currency union members & & End \\
\hline Saint Pierre and Miquelon & Benin & 1976 & Yemen & Tanzania & 1972 \\
\hline Saint Pierre and Miquelon & Burkina Faso & 1976 & Yemen & Uganda & 1972 \\
\hline Saint Pierre and Miquelon & Cameroon & 1976 & Zimbabwe & Zambia & 1967 \\
\hline Saint Pierre and Miquelon & Central African Republic & 1976 & & & \\
\hline Saint Pierre and Miquelon & Chad & 1976 & \multicolumn{3}{|c|}{ Currency unions not covered in Glick and Rose (2002) sample } \\
\hline Saint Pierre and Miquelon & Comoros & 1976 & United States & Ecuador & ongoing \\
\hline Saint Pierre and Miquelon & Congo, Republic of the & 1976 & United States & El Salvador & ongoing \\
\hline Saint Pierre and Miquelon & Côte d Ivoire & 1976 & Austria & Belgium & ongoing \\
\hline Saint Pierre and Miquelon & Djibouti & 1949 & Austria & France & ongoing \\
\hline Saint Pierre and Miquelon & Gabon & 1976 & Austria & Germany & ongoing \\
\hline Saint Pierre and Miquelon & Guinea & 1969 & Austria & Italy & ongoing \\
\hline Saint Pierre and Miquelon & Madagascar & 1976 & Austria & Luxembourg & ongoing \\
\hline Saint Pierre and Miquelon & Mali & 1960 & Austria & Netherlands & ongoing \\
\hline Saint Pierre and Miquelon & Mauritania & 1974 & Austria & Finland & ongoing \\
\hline Saint Pierre and Miquelon & Niger & 1976 & Austria & Greece & ongoing \\
\hline Saint Pierre and Miquelon & Reunion & 1976 & Austria & Ireland & ongoing \\
\hline Saint Pierre and Miquelon & Senegal & 1976 & Austria & Portugal & ongoing \\
\hline Saint Pierre and Miquelon & Togo & 1976 & Austria & Spain & ongoing \\
\hline Saint Lucia & Saint Vincent and the Grenadines & ongoing & Belgium & France & ongoing \\
\hline Saint Lucia & Trinidad and Tobago & 1976 & Belgium & Germany & ongoing \\
\hline Saint Vincent and the Grenadines & Trinidad and Tobago & 1976 & Belgium & Italy & ongoing \\
\hline Tanzania & Uganda & 1978 & Belgium & Luxembourg & ongoing \\
\hline Togo & Burkina Faso & ongoing & Belgium & Netherlands & ongoing \\
\hline United Kingdom & Bahamas & 1966 & Belgium & Finland & ongoing \\
\hline United Kingdom & Bermuda & 1970 & Belgium & Greece & ongoing \\
\hline United Kingdom & Cyprus & 1972 & Belgium & Ireland & ongoing \\
\hline United Kingdom & Falkland Islands & ongoing & Belgium & Portugal & ongoing \\
\hline United Kingdom & Gambia, The & 1971 & Belgium & Spain & ongoing \\
\hline United Kingdom & Ghana & 1965 & France & Germany & ongoing \\
\hline United Kingdom & Gibraltar & ongoing & France & Italy & ongoing \\
\hline United Kingdom & Iraq & 1967 & France & Luxembourg & ongoing \\
\hline United Kingdom & Ireland & 1979 & France & Netherlands & ongoing \\
\hline United Kingdom & Israel & 1954 & France & Finland & ongoing \\
\hline United Kingdom & Jamaica & 1969 & France & Greece & ongoing \\
\hline United Kingdom & Jordan & 1967 & France & Ireland & ongoing \\
\hline United Kingdom & Kenya & 1967 & France & Portugal & ongoing \\
\hline United Kingdom & Kuwait & 1967 & France & Spain & ongoing \\
\hline United Kingdom & Libya & 1967 & Germany & Italy & ongoing \\
\hline United Kingdom & Malawi & 1971 & Germany & Luxembourg & ongoing \\
\hline United Kingdom & Malta & 1971 & Germany & Netherlands & ongoing \\
\hline United Kingdom & New Zealand & 1967 & Germany & Finland & ongoing \\
\hline United Kingdom & Nigeria & 1967 & Germany & Greece & ongoing \\
\hline United Kingdom & Oman & 1971 & Germany & Ireland & ongoing \\
\hline United Kingdom & Samoa & 1967 & Germany & Portugal & ongoing \\
\hline United Kingdom & Sierra Leone & 1965 & Germany & Spain & ongoing \\
\hline United Kingdom & Somalia & 1967 & Italy & Luxembourg & ongoing \\
\hline United Kingdom & South Africa & 1961 & Italy & Netherlands & ongoing \\
\hline United Kingdom & Saint Helena & ongoing & Italy & Finland & ongoing \\
\hline United Kingdom & Tanzania & 1967 & Italy & Greece & ongoing \\
\hline United Kingdom & Uganda & 1967 & Italy & Ireland & ongoing \\
\hline United Kingdom & Yemen, P.D. Rep. & 1972 & Italy & Portugal & ongoing \\
\hline United Kingdom & Yemen & 1972 & Italy & Spain & ongoing \\
\hline United Kingdom & Zambia & 1967 & Luxembourg & Netherlands & ongoing \\
\hline United Kingdom & Zimbabwe & 1967 & Luxembourg & Finland & ongoing \\
\hline United States & American Samoa & ongoing & Luxembourg & Greece & ongoing \\
\hline United States & Bahamas, The & ongoing & Luxembourg & Ireland & ongoing \\
\hline United States & Belize & 1949 & Luxembourg & Portugal & ongoing \\
\hline United States & Bermuda & ongoing & Luxembourg & Spain & ongoing \\
\hline United States & Dominican Republic & 1985 & Netherlands & Finland & ongoing \\
\hline United States & Guam & ongoing & Netherlands & Greece & ongoing \\
\hline United States & Guatemala & 1986 & Netherlands & Ireland & ongoing \\
\hline United States & Liberia & ongoing & Netherlands & Portugal & ongoing \\
\hline United States & Panama & ongoing & Netherlands & Spain & ongoing \\
\hline Vanuatu & French Polynesia & 1971 & Finland & Greece & ongoing \\
\hline Vanuatu & Wallis and Futuna & 1971 & Finland & Ireland & ongoing \\
\hline Wallis and Futuna & French Polynesia & ongoing & Finland & Portugal & ongoing \\
\hline Yemen, P.D. Rep. & India & 1951 & Finland & Spain & ongoing \\
\hline Yemen, P.D. Rep. & Kenya & 1972 & Greece & Ireland & ongoing \\
\hline Yemen, P.D. Rep. & Somalia & 1971 & Greece & Portugal & ongoing \\
\hline Yemen, P.D. Rep. & Tanzania & 1972 & Greece & Spain & ongoing \\
\hline Yemen, P.D. Rep. & Uganda & 1972 & Ireland & Portugal & ongoing \\
\hline Yemen & India & 1951 & Ireland & Spain & ongoing \\
\hline Yemen & Kenya & 1972 & Portugal & Spain & ongoing \\
\hline Yemen & Somalia & 1971 & & & \\
\hline
\end{tabular}




\section{References}

Acemoglu, D., S. Johnson, and J. Robinson, 2001, "The Colonial Origins of Comparative Development: An Empirical Investigation,” American Economic Review, Vol. 91, pp. 1369-1401.

Alesina, A., and R.J. Barro, 2002, "Currency Unions," Quarterly Journal of Economics, Vol. 117, pp. 409-36.

Alesina, A., R.J. Barro, and S. Tenreyro, 2002, “Optimal Currency Areas,” NBER Working Paper No. 9072 (Cambridge, MA: National Bureau of Economic Research).

Amemiya, T., 1984, “Tobit Models: A survey," Journal of Econometrics, Vol. 24, pp. 3-61.

Baldwin, R., 2005, “The Euro's Trade Effects,” Graduate Institute of International Studies, Geneva. Presented at the June 2005 European Central Bank Conference "What Effects is EMU Having on the Euro Area and its Member Countries?"

Anderson, J.E., and E. van Wincoop, 2003, "Gravity with Gravitas: A Solution to the Border Puzzle," American Economic Review, Vol. 93, pp. 170-92.

Carrere, C., 2004, “African Regional Agreements: Impact on Trade With or Without CU's," Journal of African Economies, Vol. 13, pp. 199-239.

Coe, D.T., and A. Hoffmaister, 1999, "North-South Trade: Is Africa Unusual?” Journal of African Economies, Vol. 8, pp. 228-56.

Collier P., 1995, “The Marginalization of Africa,” International Labor Review, 134 (4-5), pp. 541-57.

Collier P., and J.W. Gunning, 1999, “Explaining African Economic Performance,” Journal of Economic Literature, Vol. 37, pp. 64-111.

Deardorff, A.V., 1998, "Determinants of Bilateral Trade: Does Gravity Work in a Neoclassical World?" in The Recolonization of the World Economy, ed. by J. Frankel (Chicago: University of Chicago Press).

Debrun, X., P. Masson, and C. Pattillo, 2005, "Monetary Union in West Africa: Who Might Gain, Who Might Lose, and Why?" Canadian Journal of Economics, Vol. 38, pp. 454-81.

Fatás, A., and A.K. Rose, 2001, "Do Monetary Handcuffs Restrain Leviathan? Fiscal Policy in Extreme Exchange Rate Regimes," IMF Staff Papers, Vol. 47, pp. 40-61.

Feenstra, R.C., J.R. Markusen, and A.K. Rose, 2001, "Using the Gravity Equation to Differentiate Among Alternative Theories of Trade," Canadian Journal of Economics, Vol. 34, pp. 430-47. 
Fielding, D., and K. Shields, 2001, "Modeling Macroeconomic Shocks in the CFA Franc Zone,” Journal of Development Economics, Vol. 66, pp. 199-223.

Frankel, J.A., 2005, “Comments on Richard Baldwin's 'The Euro's Trade Effects."” Presented at the June 2005 European Central Bank Conference "What Effects is EMU Having on the Euro Area and its Member Countries?"

Frankel, J.A., and A.K. Rose, 1997, "Is EMU More Justifiable Ex Post than Ex Ante?" European Economic Review Vol. 41, pp. 753-60.

Frankel, J.A., and A.K. Rose, 1998, "The Endogeneity of Optimum Currency Area Criteria," Economic Journal, Vol. 108, pp. 1009-25.

Frankel, J.A., and A.K. Rose, 2002, "An Estimate of the Effect of Common Currencies on Trade and Income," Quarterly Journal of Economics, Vol. 117, pp. 437-66.

Glick, R., and A.K. Rose, 2002, "Does a CU Affect Trade? The Time Series Evidence," European Economic Review (See also http://haas.berkeley.edu/ arose)

Honohan, P., and P. Lane, 2000, "Will the Euro Trigger More Monetary Unions in Africa?" Policy Research Working Paper No. 2393 (Washington, DC: World Bank).

Limao N., and A.J. Venables, 2001, "Infrastructure, Geographical Disadvantage, and Transport Costs," World Bank Economic Review, Vol. 15, pp. 471-79.

Masson, P., and C. Pattillo, 2002, "Monetary Union in West Africa: An Agency of Restraint for Fiscal Policies?” Journal of African Economies, Vol. 11, pp. 387-412. , 2004, The Monetary Geography of Africa (Washington, DC: Brookings Institution).

Persson T., 2001, “CU's and Trade: How Large Is the Treatment Effect?” Economic Policy, Vol. 33: pp. 433-48.

Pöyhönen, P., 1963, "A Tentative Model for the Volume of Trade Between Countries," Weltwirtschaftliches Archiv, Vol. 90, pp. 93-99.

Rodrik, D., 1998, “Trade Policy and Economic Performance in Sub-Saharan Africa,” NBER Working Paper No. 6562 (Cambridge, MA: National Bureau of Economic Research).

Rodrick, D., A. Subramanian, and F. Trebbi, 2002, "Institutions Rule: The Primacy of Institutions over Geography and Integration in Economic Development," NBER Working Paper No. 9305 (Cambridge, MA: National Bureau of Economic Research).

Rose, A.K., 2000, "One Money One Market: Estimating the Effect of Common Currencies on Trade," Economic Policy, Vol. 15, pp. 7-46. 
, 2001, “CU's and Trade: The Effect Is Large," Economic Policy, Vol. 33, pp. 449-57. ,2004, "A Meta-Analysis of the Effect of Common Currencies on International Trade," NBER Working Paper No. 10373 (Cambridge, MA: National Bureau of Economic Research). , 2005, “Does WTO Make Trade More Stable?” Open Economies Review, Vol. 16, pp.7-22.

Rose, A.K., and E. van Wincoop, 2001, "National Money as a Barrier to International Trade: The Real Case for CU," The American Economic Review: Papers and Proceedings, Vol. 91, pp. 386-90.

Santos Silva, J.M.C., and Tenreyro S., 2004, “The Log of Gravity,” unpublished.

Smith, C., 2002, “CU's and Gravity Models Revisited,” Reserve Bank of New Zealand Working Paper No. 7.

Subramanian, A., and N.T. Tamirisa, 2003, "Is Africa Integrated in the Global Economy?" IMF Staff Papers, Vol. 50, pp. 352-72.

Tenreyro, S., 2001, “On the Causes and Consequences of Currency Unions,” Harvard University, (unpublished).

Tenreyro, S., and R.J. Barro, 2003, "Economic Effects of CU's," NBER Working Paper No. 9435 (Cambridge, MA: National Bureau of Economic Research).

Tinbergen, J., 1962, Shaping the World Economy: Suggestions for an International Economic Policy (New York: The Twentieth Century Fund).

Yeats A., 1998, "What Can Be Expected from African Regional Trade Arrangements? Some Empirical Evidence," Policy Research Working Paper No. 2004 (Washington, DC: World Bank). 